Originally published as:

Demske, D., Heumann, G., Granoszewski, W., Nita, M., Mamakowa, K., Tarasov, P. E., Oberhänsli, H. (2005): Late glacial and Holocene vegetation and regional climate variability evidenced in high-resolution pollen records from Lake Baikal. - Global and Planetary Change, 46, 1-4, 255-279.

DOI: 10.1016/j.gloplacha.2004.09.020. 


\section{Late glacial and Holocene vegetation and regional climate variability evidenced in high-resolution pollen records from Lake Baikal}

Dieter Demske ${ }^{a,{ }^{*}}$, Georg Heumann a,b, Wojciech Granoszewski ${ }^{c, d}$, Mamgorzata Nita ${ }^{e}$, Kazimiera Mamakowa ${ }^{c}$, Pavel E. Tarasov ${ }^{\dagger}$, Hedi Oberhänsli ${ }^{9}$

a Institute of Geological Sciences, Palaeontology, Department of Geosciences, Free University of Berlin, 12249 Berlin, Germany

${ }^{b}$ Institute of Palaeontology, Friedrich Wilhelm University, 53115 Bonn, Germany

${ }^{c}$ W. Szafer Institute of Botany, Polish Academy of Sciences, 31-512 Kraków, Poland

${ }^{d}$ Polish Geological Institute, Carpathian Branch, 31-560 Kraków, Poland

${ }^{e}$ Department of Earth Sciences, Silesian University, 41-200 Sosnowiec, Poland

${ }^{f}$ Alfred Wegener Institute for Polar and Marine Research, Research Unit Potsdam, 14473 Potsdam, Germany

${ }^{g}$ GeoForschungsZentrum, 14473 Potsdam, Germany

${ }^{*}$ Corresponding author.

D. Demske

Institute of Geological Sciences, Palaeontology, Department of Geosciences, Free University of Berlin, 12249 Berlin, Germany

Tel.: +49-30-838-70275; fax: +49-30-838-70745. E-mail-address:

demske@zedat.fu-berlin.de 


\section{Abstract}

High-resolution pollen records from Lake Baikal revealed considerable regional differences in the vegetation development and pronounced climate variability during the last glacial-interglacial transition and Holocene. Correlation between cores was successfully based on a chronology constructed from $\mathrm{AMS}{ }^{14} \mathrm{C}$ dating of pollen concentrates. Comparison to other radiocarbon-dated pollen sequences from the Baikal region suggests that the chronology presented is very reliable and thus correlation to other dated events can easily be performed. Pollen indices, which reflect relative changes in major vegetation types and limitations of growing conditions by moisture availability and temperature, demonstrate near-synchronous vegetation changes, which suggest synchronous large-scale climate variation across the Baikal region. Due to the low level or even absence of human impact in the Lake Baikal region, the pollen data illustrate that in the continental interior of NE Eurasia Holocene climate variability was very pronounced. After initial warming and a strong increase in relative moisture (ca. 15-14.6 cal ka BP) the Bölling / Alleröd like event was punctuated by three cool and dry events. These events at approx. 14.2 ka BP, $13.8 \mathrm{ka}$ BP and $13.2 \mathrm{cal}$ ka BP can be compared to coolings as recorded in GISP 2 oxygen isotope records from Greenland ice cores. An expansion of Betula sect. Nane/Fruticosae, Artemisia and Chenopodiaceae marks the Younger Dryas-like cooling event (ca. 12.5-12 cal ka BP).

High temperatures and favourable moisture conditions during the first part of Holocene favoured the optimum development of dark-coniferous taiga between 10-8 cal ka BP in the south and 9.0-7.5 cal ka in the northeast. A fir and spruce decline in the southern mountains (ca. 8-7 cal ka BP) can be related to the 8.2 cal ka BP cooling event. The pronounced mid-Holocene cooling event and a transition towards dry conditions (ca. 7.0-5.5 cal ka BP) preceded the nearly synchronous regional expansion of pine taiga.

Maximum distribution of Scots pine forests marks the Holocene thermal optimum (ca. 6.5 - 5.7 cal ka BP), which was followed by two subsequent cooling events (ca. 5.5$4.8 \mathrm{cal} \mathrm{ka} \mathrm{BP}$ ) at the Atlantic-Subboreal transition. A subsequent temperature optimum in the southeastern Baikal region ended with pronounced cooling during the Subboreal-Subatlantic transition (ca. 3-2.5 cal ka BP). A late spread of shrub alders may evidence the beginning of the Little Ice Age (ca. 0.8-0.3 ka BP). 
Key words: pollen, Lake Baikal, Alleröd/Bölling, Younger Dryas, Holocene.

\section{Introduction}

Previous palynological investigations on the Lateglacial and Holocene vegetation history of the Lake Baikal region were conducted on sediment cores from the lake as well as on deposits from terrestrial outcrops, peat bogs, floodplain swamps and smaller lakes situated around the lake. Comparing the data from different regions these pollen sequences provide a record of regional vegetation changes starting with a transition from open vegetation to shrublands with willows, birches and shrub alders (Horiuchi et al., 2000; Bradbury et al., 1994). During the first warming after the Last Glacial (Sartanian) spruce and birch open forests developed. Maximum distribution of spruces occurred between ca. 12 and $11{ }^{14} \mathrm{C}$ ka BP (Takahara et al., 2000), and in the NE shrub alders were common between ca. 11 and $9{ }^{14} \mathrm{C}$ ka BP (Bezrukova et al., 1996; Kataoka et al., 2003). During the early Holocene birch, spruce and larch forests were formed in the region, while locally, steppe developed between 10 and $9{ }^{14} \mathrm{C}$ ka BP (Tarasov et al., 2002). In the northeast spruce expanded around 9 ka BP, accompanied by fir and after $8{ }^{14} \mathrm{C}$ ka BP by Siberian pine, whereas in the south taiga consisted mainly of Siberian pine and fir (Takahara et al., 2000; Kataoka et al., 2003). The optimum development of these moist forests types with spruce, fir and Siberian pine ended with a pronounced reduction of birch forests and a regional expansion of Scots pine. The mid-Holocene spread of Scots pine-dominated light-coniferous taiga started earlier in the south (ca. $7^{14} \mathrm{C}$ ka BP) than in the north (ca. $6{ }^{14} \mathrm{C}$ ka BP) (Takahara et al., 2000; Kataoka et al., 2003). During the late Holocene (around $2.5^{14} \mathrm{C}$ ka BP) larches became more abundant in light-coniferous forests (Bezrukova, 1999). Savina (1982) discussed four spruce pollen maxima in records from the NE Baikal area, which were dated to late glacial, ca. 8-7.5, 5.5-5 and 2.5-2 ${ }^{14} \mathrm{C}$ ka BP.

These studies show that there are still open questions regarding the late glacial and Holocene chronology of vegetation changes in the Baikal region and their correlation with large-scale climatic events on the Northern Hemisphere, especially as palynological analyses did not provide clear evidence of a Younger Dryas event, which is evident e.g., from oxygen isotope signatures of biogenic silica in the sediments (Morley et al., this issue). The low content of organic matter in the sediments and radiocarbon dating (Colman et al., 1996; Prokopenko et al., 1999) 
provide difficulties in establishing age control for records of environmental and climatic changes based on cores from Lake Baikal.

This paper presents new pollen records from three coring sites in the North and South Basin of Lake Baikal (Fig. 1). Palaeoenvironmental signals recorded in the sediments of this large freshwater lake are assumed to reflect large-scale vegetation and climate changes. However, regional differences should be evident as the coring sites are located in vicinity to the Barguzin Range in the NE, the Khamar-Daban Range in the $S$ and the Selenga Delta and catchment area in the SE, which comprises low mountains of the eastern Khamar-Daban Range and the trans-Baikal forest-steppe region. Furthermore, pollen records reflect altitudinal shifts in mountain vegetation as a response to climatic changes in the area.

High-resolution pollen records, supported by a chronology based on $\mathrm{AMS}{ }^{14} \mathrm{C}$ dating of pollen concentrates, were elaborated in order to highlight (1) details of the vegetation history in the Baikal region during the last glacial-interglacial transition (Termination I) and Holocene, (2) regional differences in vegetation changes in comparison with other records from East Siberia and Mongolia, and (3) vegetational fluctuations caused by large-scale climate variability across the region.

\section{Settings}

The relief of the Baikal region is highly differentiated, due to tectonic processes in the Baikal Rift valley, formation of mountain ranges and valley incisions (Mats, 1993; Levi et al., 1997; Lut, 1978). The Primorskiy and Baikalskiy Mountain Ranges stretch along the western coast, whereas the Barguzin Range rises in the northeast, and the Khamar-Daban Range limits the Baikal basin in the south (Fig. 1). The largest inflowing rivers are the Upper Angara from the north, the Barguzin from the northeast, and the Selenga from the southeast. The Selenga River constitutes the main inflow from a catchment area extending into the trans-Baikal region and northern Mongolia. It forms a large delta area in the southeastern part of Lake Baikal. Numerous minor rivers may also influence sedimentation in the lake (Lut, 1978; Karabanov, 1982).

The regional and altitudinal distribution of modern vegetation is controlled by the relief as well as by temperature and precipitation gradients across the region. Mean annual precipitation (MAP) at the northern slope of the Khamar-Daban Range is much higher than in vicinity of the other two coring sites (Fig. 1; Table 1), but with 
increasing altitudes in the mountains values generally exceed $1200 \mathrm{~mm}$ (Galaziy, 1993). In the Barguzin Range (Fig. 2A) MAP amounts to $500-800 \mathrm{~mm}$ in the forest subzone of mixed taiga forests (600-850 $\mathrm{m}$ a.s.I.), $800-1000 \mathrm{~mm}$ in the upper subzone with spruce - fir forests (850-1150 m), and between 1000 and $1300 \mathrm{~mm}$ in the subalpine and alpine zones (Tyulina, 1976).

Generally, Scots pine (Pinus sylvestris) and larch (Larix) taiga prevails on dry eastfacing mountain slopes, whereas Siberian pine (Pinus sibirica), fir (Abies sibirica) and spruce (Picea obovata) taiga is widespread on moister north- and west-facing slopes of mountain ridges. East of Lake Baikal Larix sibirica is replaced by $L$. dahurica (Belov, 1972; Bezrukova, 1999), and birches (Betula) and poplar trees (Populus tremula) may replace Scots pine- larch - taiga.

The lower forest subzone on the west-facing slopes of the southern Barguzin Range (456-600 m a.s.I.) comprises larch forests and pine scrubs (Pinus pumila) (Fig. 2A). Scots pine prevails in the subzone of mixed taiga forest (600-850 m). In the upper forest subzone (850 and $1150 \mathrm{~m}$ ) the forest communities are formed by Siberian pine and fir, the latter prevailing above $1000 \mathrm{~m}$. Open park forests and scrubs with fir and birches grow at the upper forest boundary between 1150 and $1350 \mathrm{~m}$ (Tyulina, 1976). A similar vegetation distribution occurs on Svyatoy Nos Peninsula. Further north larch, Siberian pine and spruce reach the upper forest limit (Belov, 1972). The Selenga River delta and neighbouring areas comprise aquatic, mire and willow shrub vegetation, as well as forests with birches, Scots pine and larches (Molozhnikov, 1981; Granina and Votyakova, 1981). In the Khamar-Daban Range (Fig. 2B), due to higher precipitation as compared with the Barguzin Range (Table 1), spruce, fir and Siberian pine taiga descends down to $600 \mathrm{~m}$ a.s.l. Fir park forests occur at altitudes of 1200-1500 m reaching the subalpine forest boundary (Molozhnikov and Molozhnikova, 1988).

At the upper forest limit in the Barguzin and Khamar-Daban Ranges shrub alders (Duschekia fruticosa $=$ Alnus fruticosa), willows (Salix), shrub and dwarf shrub birches (Betula sect. Fruticosae and sect. Nanae) and scrub pine (Pinus pumila) form various communities, intermingled with meadows, subalpine forb meadows and fern thickets (Fig. 2). Alpine plant communities comprise scrub pine and Rhododendron aureum (up to ca. 2000 m a.s.I.), dwarf shrub tundra with Salix, Betula nana and Ericaceae, scarce vegetation on rubble and rocks and fragments of mountain meadows including subnival patches (Belov, 1972; Tyulina, 1976; Molozhnikov and 
Molozhnikova, 1988). Steppe and pine forest-steppe (Pinus sylvestris) as well as elm (Ulmus pumila) occur within the Selenga catchment area in the trans-Baikal region. Further north steppe areas are limited to the Barguzin River basin, Olkhon Island and the Priolkhon region (Belov, 1972). However, within the whole region patches of steppe and rock-steppe vegetation occur on east- and south-facing slopes, often with Selaginella sanguinolenta or S. rupestris.

\section{Material and methods}

\subsection{Investigated cores}

Coring sites in Lake Baikal were selected based on high-resolution seismic reflection profiles (Charlet et al., this issue), and three elevated near-shore areas of continuous sedimentation were chosen for investigations (Fig. 1). Holocene sediments are rich in clay and diatoms, whereas glacial deposits generally consist of silty clay with few diatoms and include coarse mineral grains and ice-rafted detritus (Francus, 1999; Fagel et al., this issue; Demory et al., this issue). Continent Ridge stretches ca. 5-15 $\mathrm{km}$ north of the Svyatoy Nos Peninsula and ca. $25 \mathrm{~km}$ from the northeastern coast. A kasten core with $15 \times 15 \mathrm{~cm}^{2}$ in cross-section (Kögler, 1963) and a length of $396.5 \mathrm{~cm}$ was retrieved at a water depth of $386 \mathrm{~m}$ (CON01-603-5, 53⒌'17"N, 10854'49"E). The upper oxidised layer $(14.5 \mathrm{~cm})$ was finely to coarsely laminated and consisted of diatom-rich clayey silt with frequent iron-manganese nodules. Below, sediments were diffusely to finely laminated, downwards changing into silty clay and clay with silt. Coarse mineral grains $>0.4 \mathrm{~mm}$ were rare within the oxidised core top, common in the middle and more frequent in the lower part of the investigated core section (down to $120 \mathrm{~cm}$ ). Oxidation of bottom sediments in the North Basin of Lake Baikal can be favoured by cool climatic conditions, low diatom bioproductivity and relatively low sedimentation rates (Granina, 1992).

Posolskoe High is situated ca. $30-35 \mathrm{~km}$ southwest of the Selenga delta margin. The water depth at the coring site $\left(52^{\circ} 05^{\prime} 02^{\prime \prime} \mathrm{N}, 105^{\circ} 51^{\prime} 55^{\prime \prime} \mathrm{E}\right)$ was $130 \mathrm{~m}$, and the obtained kasten core (CON01-606-3) had a length of $363 \mathrm{~cm}$. The upper homogenous sediments comprised diatom-rich clayey silt with a weakly oxidised top layer, whereas the silty clay below was diffusely to finely laminated. In the lower part of the investigated core section (down to $125 \mathrm{~cm}$ ) the composition changed into clay with silt.

Vydrino Shoulder is located at a distance of ca. $5 \mathrm{~km}$ from the southern coast in the 
vicinity of several underwater channels (Charlet et al., this issue). The two coring sites were situated at a distance of ca. $250 \mathrm{~m}$ from each other, as estimated from the coordinates. A Kasten core of $176.5 \mathrm{~cm}$ length (CON01-605-5, 51 ${ }^{\circ} 35^{\prime} 01^{\prime \prime} \mathrm{N}$, $\left.104^{\circ} 51^{\prime} 06^{\prime \prime E}\right)$ was recovered at a water depth of $665 \mathrm{~m}$. The sediments were diffusely to finely laminated and comprised of clayey silt in the upper part and silty clay in the middle and lower sections of the core. A piston core of $12 \mathrm{~cm}$ diameter and $1051.5 \mathrm{~cm}$ length (Meischner and Rumohr, 1974) was retrieved from a water depth of $675 \mathrm{~m}$ (CON01-605-3, 51 $\left.{ }^{\circ} 35^{\prime} 06^{\prime \prime} \mathrm{N}, 1^{\circ} 4^{\circ} 51^{\prime} 17^{\prime \prime E}\right)$, complemented by a pilot core with a length of $173 \mathrm{~cm}$. The piston core revealed sediments with coarse irregular laminations and comprised of silty clay to clayey silt $(0-75 \mathrm{~cm})$, clay with silt and fine sand $(75-107 \mathrm{~cm})$, then again silty clay to clayey silt, but with fine sand. Several sandy levels of 3-5 cm thickness occurred just below $170 \mathrm{~cm}$ depth.

\subsection{Sample processing, counting and pollen zonation}

Sediment slices of $0.5 \mathrm{~cm}$ thickness were obtained from gravity core segments, and of $1 \mathrm{~cm}$ thickness from the Vydrino piston core. Volumetric subsamples of $5 \mathrm{~cm}^{2}(10$ $\mathrm{cm}^{2}$ in case of the lowermost samples from Continent core) were prepared according to standard procedures including $7 \mu \mathrm{m}$ ultrasonic fine-sieving (Cwynar et al., 1979; Fægri et al., 1989; PALE, 1994). Two tablets of Lycopodium marker spores were added to each sample for calculating total pollen and spore concentrations (Stockmarr, 1971). Water-free glycerol was used for storage and preparation of microscopic slides. The palynological samples were counted at magnifications of 400-600x, applying 1000x for the identification of difficult pollen types, e.g. including Saxifragaceae, Crassulaceae and Rosaceae.

Generally, preservation of palynomorphs was good to very good, although corroded grains were present and bisaccate pollen types of Pinus, Picea and Abies were frequently broken. The pollen and spore content of the samples was sufficiently high to count basic sums of 500-1000 arboreal and non-arboreal pollen (AP+NAP). For the Continent core CON01-603-5 the basic sums mostly reached 1000-1500 grains, but only 100 to 250 grains or less could be evaluated in glacial sediments (below 103 $\mathrm{cm})$ and within the oxidised top section $(16-3.5 \mathrm{~cm})$. Corrosion and differential destruction of some pollen types was most severe at 13-7.5 cm, and counted spectra here are distorted and reveal very low concentrations.

Calculation of percentages was based on the AP+NAP basic sums, which exclude 
pollen of aquatic plants, pteridophyte spores, Sphagnum moss spores, non-siliceous algae, long-distance transported or reworked pollen and spores, and indeterminate pollen and spores. For these taxa percentages were calculated using the basic sum plus all counts within the selected group. All pollen sequences were subdivided based on square-root transformed percentage data and stratigraphically constrained cluster analysis by the method of incremental sum of squares (Grimm, 1987). The numerically delineated local pollen assemblage zones (LPAZ) and subzones (LPASZ) were numbered from bottom to top, assigning prefixed letters for core locations: C - Continent Ridge, P - Posolskoe High, V - Vydrino Shoulder and VH Vydrino Shoulder (piston core, Holocene). Several smaller units within subzones (zonules according to Birks and Birks, 1980) were introduced in order to facilitate correlation between cores.

\subsection{Taxonomic remarks}

Pinus grains were determined as $P$. sibirica-type (including pollen of scrub pine $P$. pumila) or $P$. sylvestris-type, but due to size variation (Beug, 1961) and fragmentation both types may imply a taxonomic overlap. Birch pollen grains were assigned to two morphological types, Betula sect. Albae or B. sect. Nanae/Fruticosae and in case of the Continent record, further separating $B$. sect. Nanae which includes pollen of B. nana dwarf shrubs (Blackmore et al., 2003; Birks, 1968; Gaillard, 1983). Rosaceae undiff. summarises pollen of shrubs and trees as well as undetermined non-arboreal taxa, but was assigned to the arboreal group, because Sorbus prevailed in the Continent record. It should be noted that pollen grains of Duschekia fruticosa (Alnus fruticosa) from late glacial core sections were very small and delicate.

Counts of Alnus hirsuta-type were included into the basic sum because the modern East Siberian distribution area of $A$. hirsuta reaches the Baikal region. In Holocene records from Yakutia this pollen type is frequent with up to $2 \%$ presence (Velichko et al., 1997). Generally, the contribution of pollen and spores from redeposition and atmospherical far-transport was of minor importance. However, in the lower sections of the Posolskoe and Continent cores Alnus hirsuta-type reached 2.5-5\%, very likely including rebedded grains ( $A$. glutinosa, $A$. incana) in coincidence with presence of sporomorphs ascribed to atmospheric long distance-transport or redeposition (Osmunda spores, exotic tree pollen). Alnus pollen and Osmunda spores are 
common in Late Tertiary deposits (Belova, 1985), which occur on the southern coast of Lake Baikal, in the Selenga Delta area, on Olkhon Island and the Priolkhon Area as well as on Svyatoy Nos Peninsula and in the Barguzin Valley (Mats, 1993).

\subsection{Pollen indices}

Relative changes in major vegetation types can be shown by assigning recorded taxa to groups in correspondence to the modern spatial and altitudinal distribution of plant communities (Fig. 2) and calculating percentage subsums for the generalised pollen data. The applied classification (Table 2) corresponds to grouping of taxa applied in the biome approach (Tarasov et al., 1998, 2000), but includes minor modifications with respect to the recorded pollen type diversity and geobotanical characteristics of the region. Tree birches (Betula sect. Albae) were included in the group of birch subtaiga and forest-steppe, although birches can occur in a wide range of forest communities. In southern West Siberia modern birch forests with bracken fern (Pteridium aquilinum) are widespread (Walter, 1974; Grichuk, 1984; Monserud et al., 1998). Ulmus pumila occurs in pine forest-steppe environments of the southern trans-Baikal region. Steppe, forest-steppe and light-needled taiga represent relatively dry vegetation types, whereas dark-needled taiga and shrubs require moist growing conditions (Table 2). Shrubs of the subalpine zone (Duschekia fruticosa, Rhododendron) and boreo-alpine taxa indicate relatively cool and moist growing conditions. However, in arctic Siberia Holocene spreading phases of shrub alders occured during relatively warm periods (Andreev et al., 2003; Pisaric et al., 2001). Vegetational indices based on ratios of pollen subsums reflect relative, but not proportional changes in major plant formations (Whitlock, Bartlein, 1997; White et al., 1997). Indices M and T used in this paper (Table 2) are related to growing conditions influenced by moisture availability and temperature, respectively. Square-root transformation was applied to the ratio values in order to outweigh strong variations caused by percentage maxima of Duschekia and Pinus sylvestris-type and low abundance of Abies and Larix. The latter are generally under-represented in pollen surface samples from the Baikal region (Kataoka et al., 2003).

\section{Age models and core correlation}

Age models were constructed based on AMS ${ }^{14} \mathrm{C}$ dating of pollen concentrates from sediment samples (Piotrowska et al., 2004). Linear regression (Colman et al., 1996; 
Anderson et al., 2002) was applied to data subsets for each core in order to account for changes in sedimentation rates (Fig. 3). In the Posolskoe core ages below $80 \mathrm{~cm}$ depth were inferred by comparison with pollen zone and subzone boundaries of the Continent record, because ages from the ${ }^{14} \mathrm{C}$ datings are too old, most probably due to an increased input of old terrestrial carbon from the Selenga River (Figs. 3A and 3B).

The uppermost dating for the Vydrino Kasten core was also rejected, because it suggests an unlikely strong increase in sedimentation rates (Fig. 3C). Five additional AMS 14C dates (Fig. 3C) for the Vydrino piston core extend the previous age model for this location published by Piotrowska et al. (2004). The pollen records from both Vydrino cores were combined into a composite sequence, with a tie point around 11 cal ka BP in agreement with a palynostratigraphical correlation. Extrapolation of regression lines to the core tops rendered apparent surface ages of ca. 930, 675 and 960 ka BP for the Continent, Posolskoe and Vydrino Kasten cores, respectively (Piotrowska et al., 2004). At all sites the topmost surface sediments are missing due to the coring technique. Throughout this paper calibrated ages are used, if not stated otherwise.

\section{Regional pollen stratigraphy and vegetation history}

In the following section we describe the characteristic vegetation changes occurring from the Termination I through the Holocene. We distinguish 7 vegetation scenarios and report their most characteristic botanical features.

\subsection{Open landscape with steppe and dwarf-shrub tundra (LPAZ C-1, P-1, V-1)}

The first change is characterised by abundant non-arboreal taxa and common shrub and dwarf shrub birches (Betula sect. Nanae/Fruticosae), willows (Salix) and shrub alders (Duschekia fruticosa). Furthermore, pine scrub communities with Pinus sibirica-type (including $P$. pumila pollen) appear while trees are still rare or absent. In the lower part of this zone, Betula sect. Albae and Pinus sylvestris-type are relatively abundant, though sporomorph concentrations in general are still low. We infer that they indicate long-distant transport or reworking of older sediments. Assemblages from southern and northern sites differ slightly. Artemisia, Chenopodiaceae and Asteraceae subfam. Cichorioideae prevailed in steppe communities of the northeastern Baikal region Patches of rock-steppe with Selaginella rupestris and $S$. 
sanguinolenta are typical for the higher altitudes sites in the S- and N-facing mountains (Fig. 4). To the S (Posolskoe and Vydrino Sites) grass steppe with Poaceae, Artemisia and Chenopodiaceae formed the dominant vegetation (Figs. 5 and 6). Towards the top of this zone, shrub communities spread and open vegetation diminishes.

\subsection{Expansion of willows, spread of shrub alders and appearance of spruce trees (LPASZ C-2, P-2, V-2)}

The transition towards shrub-dominated vegetation is rather rapid and is evident at all three studied sites. Willow (Salix) is common while non-arboreal pollen decreased progressively from $\mathrm{N}$ to $\mathrm{S}$ indicating the retreat of steppe and tundra vegetation (Figs. 4-6). There are a few site-specific plant communities, like sedge populations (Cyperaceae), dwarf-shrub and shrub birches and shrub alders, which become more important in the $\mathrm{N}$ Baikal area. The pollen record from Posolskoe High shows that in the delta area very dense willow vegetation had established, while at higher altitudes of the Khamar-Daban mountains (CON01-605-3) grass-dominated communities persisted, though with slightly decreasing abundance. Shrub alders spread later in the $S$ than in the N Baikal area (CON01-603-5; Fig. 4).

Subsequently Salix decreased, and Duschekia increased, indicating a late spread of shrub alder communities in the region around the Selenga Delta, while in the mountains shrub alders, ferns (Filicales Monoletae) and clubmosses (Lycopodium) became more abundant. Birch trees established first of all, adjacent to the Selenga Delta (Fig. 5), and an initial, small spruce pollen maximum in the Vydrino record indicates its early spread near the Khamar-Daban Range (Fig. 6). Only shortly later, spruce trees (Picea obovata) spread nearly synchronous at the southern and northern sites. In the $\mathrm{N}$ mountain faces, Sorbus trees (included in Rosaceae undiff.) and ferns (Filicales Monoletae) established before this coeval event (Fig. 4), and then the willows became successively replaced by shrub alders and some steppe taxa (Poaceae, Artemisia, Asteraceae, Thalictrum, Sedum-type). At Vidrino Site, showing the most complete record, a second distinct Duschekia pollen maximum (together with a lowered Picea pollen concentration) was recorded (Fig. 6). In the N Basin and also at the Posolskoe Site this change is probably documented by a small increase in Asteraceae subfam. Cichorioideae (Figs. 4, 5). 


\subsection{Development of spruce open forests and of birch and pine forest-steppe (LPASZ C-3a, P-3a, V-3a) followed by decline of forest vegetation and expansion of shrub alders (LPASZ C-3b, P-3b, V-3b)}

In the N Basin we recorded an intensive spread of Picea pollen, which persisted for a relatively long period before being replaced by Betula sect. Albae and Artemisia (Fig. 4). Spruce trees occurred throughout in the S Baikal region, although were less abundant than in the $\mathrm{N}$ Baikal region. Furthermore, birch forests, and possibly even larch woods, are typical for this region too (Fig. 6). For the Selenga area, with a low relief, spruce forests could only establish for a short time (Fig. 5), and instead birch forests developed well together with a shortly lived pine-forest steppe vegetation, as documented by the Pinus sylvestris-type pollen (Fig. 5). Towards the top of this zone, evidence of an environemental shift was heralded when spruce diminished and forest-steppe spreads instead.

Our data suggests that soon after, an intensive expansion of shrub alders occurred in the $\mathrm{N}$ together with shrub alders although these were less abundant. A dense Salix population (Fig. 6) persisted in the S, due to locally favourable hydrological conditions in the Selenga Delta area (Fig. 5). We observed minor peaks of Betula sect. Albae and Picea in the Vydrino pollen indicating that scarce birch and spruce open forests still existed in the Khamar-Daban Mountains (Fig. 6). Abundant Asteraceae subfam. Cichorioideae in the Continent and Posolskoe records (Figs. 4, 5), and the nearly continuous presence of Huperzia spores in the Vydrino pollen sequence are typical steppe and subalpine elements.

In the upper part of the subzone, Duschekia decreased and tree pollen and birch shrubs gradually increased. Open forests with birches (Betula sect. Albae), spruce (Picea) and larches (Larix) developed in the N (Fig. 4) and S Baikal Basins. A small increase in these taxa in the Vydrino record (Fig. 6) might be indicative of a tree refugia nearby which resulted in an early reappearance of birch and spruce forests in the southern Baikal region. In contrast, the Posolskoe record shows a considerable rise in non-arboreal pollen, which reveals that a spread of steppe vegetation in the low-altitude region to the SW was favoured by increasingly dry conditions (Fig. 5). This reduced forest cover and expansion of shrub alder, which may be indicative of a severe cooling, perhaps related to the Younger Dryas event. Towards the top of this zone open forests developed again. All pollen records show a considerable decline in Duschekia percentages, and a pollen-stratigraphical subdivision between zones 
becomes more distinct.

\subsection{Development of open forests and taiga (LPAZ C-4, LPASZ P-4a, LPAZ V-4 and $\mathrm{VH}-4)$}

At the base of this zone shrub alders were still widespread, but retreated steadily in the NE. Open forests with birches and larches developed on dry sites, while spruce open forests and birch shrub communities were more common at moist sites (Fig. 4). In the south, steppe vegetation remained dominant in the lower part of the zone as shown by increased NAP percentages in the Posolskoe sequence, whereas in the Selenga Delta area willows remained abundant, probably due to high moisture supply from the river (Fig. 5). The Vydrino pollen record indicates a spread of spruce open forests and intense development of birch shrubs and fern thickets, on future potential sites of moist, coniferous forests. This development indicates improved moisture conditions at higher altitudes in the southern mountains (LPASZ V-4a; Fig. 6). However, the forest development in the whole Baikal region was still limited, especially in the north, as suggested by the persistence of shrub alders and open forests with larches, spruces and Sorbus.In the south on the other hand, the rather dry conditions favoured open steppe environments and probably acted to limit the distribution of birch and spruce forests.

Subsequently, the forest development in the northeast is shown by increased abundance of spruce pollen, pointing to denser spruce (Picea) forests on moist sites, and these partly replace shrub alder communities. From the Continent Site record we infer that Siberian pine (Pinus sibirica) and fir (Abies sibirica) were only of minor importance, as their pollen were still very rare, whereas birch and larch forests were more widespread. Larches, associated with Juniperus shrubs, formed dry forest types (LPASZ C-4b; Fig. 4), and despite the general abundance of ferns (Filicales Monoletae), bracken (Pteridium aquilinum) was not yet present in vicinity of the Barguzin Range.

The Posolskoe pollen record shows a further expansion of steppe in the south as well as a spread of Ulmus (U. pumila) and Ephedra. An early development of moist forest types with fir in the low mountainous area (near the Selenga Delta area) only starts in the upper part of LPASZ P-4a (Fig. 5). However, the Vydrino data show that under moist conditions, probably at higher altitudes, fern thickets were very common. They herald the establishment of dark-coniferous taiga with Pinus sibirica, Picea spp. 
and Abies spp. Bracken fern appeared quite early in the Khamar-Daban mountain area, most likely as an element in birch forest-steppe environments, together with forests with Scots pine (LPASZ V-4b; Figs. 6). Furthermore, the Vydrino record reveals maxima of shrub alder pollen in coincidence with increasing pollen percentages of Siberian pine and fir, which indicate the development of forest types indicative or moister conditions (LPASZ VH-4c; Fig. 6).

\subsection{Optimum development and decline of dark-coniferous taiga (LPAZ C-5, LPASZ P-4b and LPAZ P-5, LPAZ VH-5)}

The pollen record from the NE reveals maximum distribution of dark-coniferous spruce-dominated coniferous forests, with modifications in the composition due to the gradual spread of Siberian pine (Pinus sibirica) and appearance of fir (Abies) (LPAZ C-5). Birch forests too were widely distributed. Fir and Siberian pine showed a maximal spread during the optimum development of dark-coniferous taiga in the NE. On drier habitats, however, larch (Larix) forests expanded. The extension of bracken fern (Pteridium) may be related to relatively open birch forests (LPASZ C-5a; Fig. 4). A pronounced minimum in Picea pollen (in the uppermost part of LPASZ C-5a) corresponds to a decrease in Pinus sibirica-type and increases in Duschekia, Pinus sylvestris-type and non-arboreal pollen. These changes record a distinct vegetational transition, which reflects cooler and increasingly dry conditions in correspondence to a first major spread of Scots pine in the northeast (LPASZ C-5b), which occurred considerably later than in the south. After this disturbance in dark-coniferous taiga, spruce and Siberian pine recovered, whereas the distribution of fir, birch forests and birch shrub-lands became considerably reduced.

In the Posolskoe record spruce pollen is not frequent and fir nearly absent, but percentages of both Scots pine and Siberian pine show a major rise, in combination with a decrease in non-arboreal pollen (LPASZ P-4b; Fig. 5). Subsequently, the continuous record of fir pollen points to the optimum development of dark-coniferous taiga in the neighbouring mountains, but still Siberian pine dominated in the area (LPAZ P-5). The wide distribution of birch and larch forests, as well as the high abundance of bracken fern in this region, point to relatively dry conditions; this would explain the relatively early spread of Scots pine (Pinus sylvestris) in the S Baikal region. Finally, a reduction in spruce, fir and birch and a further major spread in Scots pine becomes, like in the NE, characteristic for the forests in S region (LPASZ P-5b). 
In the Vydrino record the dark-coniferous taiga is documented by an initially high contribution of spruces and firs (LPASZ VH-5a; Fig. 5), but later Siberian pine becomes dominant. After a temporary reduction ( $\mathrm{VH}-5 \mathrm{~b}$ to $-5 \mathrm{c}$ ) spruces and firs could recover in dark-coniferous forest types $(\mathrm{VH}-5 \mathrm{~d})$ too. Abundance of bracken fern is associated with a wide distribution of birch forest-steppe in the Khamar-Daban Mountains. In contrast to the wide distribution of larch forests in the NE, dry forest types in the $S$ mountain region were mainly formed by Scots pine, which exhibits several spreading pulses especially when shrub alders are less abundant (LPASZ $\mathrm{VH}-5 \mathrm{~d}$ ). As to the Vydrino Site, fir and spruce decline, and become replaced by shrub alders (LPASZ VH-5e).

\subsection{Spread of Scots pine - larch taiga (LPAZ/LPASZ C-6 to C-7a, P-6, VH-6a to $\mathrm{VH-6d-1)}$}

A nearly synchronous rise in Pinus sylvestris-type occurred in all studied sequences. Though the Scots pine is dominating this zone, maximum distribution was reached relatively late in the NE as spruce declined only slowly (LPASZ C-6a, Fig. 4).

Decreasing Picea percentages point to a more gradual shift of the dark-coniferous taiga towards higher altitudes due to a change from moist to dry conditions in the lower forest zones of the Barguzin Range. Today the Pinus sibirica-type record stands for a major spread of Siberian pine in dark taiga communities recorded below the upper Abies forest zone (Fig. 2). Lowered abundance of shrub alder communities, a decline in larch forests and the expansion of Scots pine forests point to more favourable conditions than in the transitional interval, but also suggests lower moisture in the NE Baikal region.

In the south Scots pine expanded very rapidly (Figs. 5 and 6). According to the Vydrino record only fir but not Siberian pine and spruce were subject to a reduction, probably due to moist conditions even in lower altitudes of the Khamar-Daban Range (Table 1).

During the further vegetation development the Continent Site (LPASZ C-6b)

evidences strong fluctuations in Scots pine and spruce forests together with a spread of open vegetation and shrub communities and increased abundance of clubmosses (Diphasiastrum, Lycopodium). Again larches could spread, and steppe communities with Artemisia, Chenopodiaceae, Selaginella sanguinolenta and S. rupestris formed. Subsequently, the vegetation development in the northeast was characterised by a 
pronounced expansion of larch forests. In the south no change in open vegetation is recorded, but forests were affected by a reduction in spruces and bracken fern (Pteridium). The Posolskoe record (LPASZ P-6b) evidences slightly increased abundance of Siberian pine (Fig. 5) while in the Khamar-Daban Range (LPASZ VH6c) abundance of Scots pine forests fluctuated, and birch forests and later also larches could spread (Fig. 6).

\subsection{Spread of larch forests (LPAZ/LPASZ C-7a to C-8, P-7, VH-6d-2 to VH-6e)}

The upper section of the Posolskoe pollen record shows strong fluctuations in Scots pine forests and a spread of birch shrub communities and open vegetation. A first interval with lowered abundance of Scots pines (LPASZ P-7a) was marked by increased abundance of tree birches, willows and shrub alders as well as steppe communities with grasses, Artemisia and Chenopodiaceae/Amaranthaceae (Fig. 5). A similar but long-lasting interval is also shown by the Vydrino record, which evidences a distinct spread of larch forests and ferns in the Khamar-Daban mountain area (LPASZ VH-6d-2; Fig. 6).

Further advances of steppe communities in the Selenga Delta area corresponded to a further spread of shrub birches and a late spreading phase of shrub alders, which is also recorded in the topmost part of the Vydrino record (Figs. 5 and 6).

Despite oxidative corrosion and differential pollen destruction the Continent record suggests high abundance of tree birches, larches and shrub alders in the northeast (Fig. 4). Moreover, increased frequencies of Sphagnum moss spores are in agreement with obsevations from the south. The undistorted pollen assemblages in the topmost part of the Continent record (LPASZ C-8b) do not evidence major vegetation fluctuations, but reveal a wider distribution of larch and spruce forests whencompared to the southern region.

\section{Palaeoclimate variability - chronology and regional comparison}

Based on the vegetation changes outlined in the previous chapter we discuss below the most prominent Central Siberian climatic changes. Correlation between the NE, SE and S Lake Baikal coring sites is build on ${ }^{14} \mathrm{C}$ dating and partly on pollen zones (Figs. 7-9). We will focus on relative temperature and humidity changes as inferred from pollen records for the Termination I and Holocene. In analogy to Holocene 
spreading phases of shrub alder in arctic Siberia during warmer periods (Andreev et al., 2003; Pisaric et al., 2001) the pollen index T may possibly underestimate the relative temperature increase within the Termination I. The relative temperature pattern ( $T$ index; Figs.7-9) shows distinct changes through the Termination I and the Holocene, which easily can be correlated with climatic variations known from other regions. From the Termination I (Fig. 9), the Bölling/Alleröd- and Younger Dryas-like events can be inferred. During the Holocene the most prominent changes are the Preboreal oscillations, and the Mid-Holocene climatic optimum. Some cooler events such as at 7,5 cal ka BP and 8,2 cal ka may be traced too. The relative humidity (M Index; Figs.7-9), however, shows a major increase during the Termination I followed by a gradual decrease before it levels off to present day values during the MidHolocene optimum.

\subsection{Climate changes during the last glacial-interglacial transition (Termination I)}

During the latest Sartan Glacial and the Termination I modifications in vegetation cover show a similar pattern across the studied area which given the extended catchment, covers by far more then $1000 \mathrm{~km}$ in latitude. Though the estimated temperature and humidity changes indicate only relative values the amplitude of changes across the studied time window is quite similar at the three studied sites (Fig. 8). The curves supplied for the three sites document that inferred climate changes are due to temperature but more to humidity changes. Only shortly after the LGM, succession of vegetation highlights a climatic amelioration. Initial evidences for a vegetation cover occurred well before 15,80 cal ka BP indicating a gradual warming due to increasing insolation. The progressive warming, which caused glaciers to melt and permafrost to thaw deeper then during the short glacial summer triggered soon a first expansion of shrub communities in the catchment area of Lake Baikal (Subzones $1 \mathrm{a}+\mathrm{b}$; Fig. 7-9). During the early vegetation phase humidity did not change significantly. Yet the warming was moderate because shrub alder (Duschekia fruticosa) is still an indicator taxon for relatively cool conditions since even today it is restricted to the subalpine mountain zones of the Baikal area (Fig 2). A significant climatic improvement occurred between 14,35 and 12,7 cal ka BP (Figs. 4 to 9) when first the willows and later the alder shrub expanded (Subzones $2 a+b)$. This climate change was related to a warming but more important then the temperature increase 
was the raising humidity. It caused a fundamental vegetation change in Central Siberia. We correlate this change, when Salix pollen increase and Duschekia fructicosa became abundant (Zones $2 a+b)$, to the Bölling s.l. / Alleröd s.l. complex $(B / A)$, which is unknown from previously described records from Central Siberia, but is well established and dated in W European sections and in the $\mathrm{N}$ Atlantic realm (e.g., van Geel et al., 1989; Litt, Stebich, 1999). In Europe and in the GISP II record this interval is dated 14,6-12,8 cal ka BP (Steig et al, 1998) and the Siberian B/A-like event which is represented by Zones $2 a$ through $3 b$ falls within this time range (Figs. 7-9). The B/A event has been observed at all 3 studied sites.

According to Horiuchi et al., (2000) distinct maxima of Salix and Duschekia (Alnus) fruticosa pollen occur between 16 and $13{ }^{14} \mathrm{C}$ ka BP on the submersed Academician Ridge. From peat bogs at the southern shore of Lake Baikal a maximum distribution of spruces (Picea) has been observed between ca. 12 and $11{ }^{14} \mathrm{C}$ ka BP (Takahara et al., 2000). In the lower part of the Dulikha sequence, Bezrukova et al. (2000) described that shrub pollen (Betula sect. Nanae, Duschekia fruticosa, Salix) are common before $11 \mathrm{ka}$ BP but then stated to decline. This seems to be ample evidences for a widespread A/B event, which seem to be present in other locations too, though the ages reported by Horiouchi et al. (2000) may be to old as they are possibly biased by an admixture of dead carbon.

Thereafter, shrub alder abundance decline in the Virdino record, while Betula sect. Nanae/Fructicosae, Artemisia, Chenopodiaceaea and Filicales Monoletae undiff. increased (Zones 4a+b; Fig. 9). This points towards a cooling. This interval has been dated to cover at least the interval 12,7 to $12.3 \mathrm{cal}$ ka BP. The dated interval falls within an event which in European sites is the Younger Dryas (YD) event dated to last from $13 \mathrm{ka} \mathrm{cal}-11,7 \mathrm{cal}$ ka BP. Though this event can only be clearly outlined at Vidrino Site, the site with the most complete record and highest sedimentation rate, there are some minor changes which also point towards a cooling within Subzone $4 \mathrm{a}$ at the Posolskoe (distinct rise in Artemisia and Chenopodiaceae/Amaranthaceae pollen) and Continent Sites and therefore could be taken as evidence for the YD-like event too (Fig. 7,8). At all sites moisture conditions decreases from YD and onward as shown by larch forests which develop in the $\mathrm{N}$ and the expansion of steppe in the SE (Zone 4; Figs. 7-9). Younger Dryas like events have been reported earlier from other sites in Siberia. Andreev et al., (1997) reported on a Younger Dryas-like event from the Suollakh peat-bog in Southern Yakutia. They observed a decline in spruce, 
larch and an increase in non-arboreal taxa. Similarly in Central Yakutia, abundance of arboreal pollen (mainly Betula sect. Albae), decreased, and at the same time Artemisia increased in lake sediments of Khomustakh and Chabada between ca. 11 and 10 ka BP (Andreev et al., 1997; Velichko et al., 1997). Furthermore in NE Siberia, near the Lena Delta, Cyperaceae, Poaceae and Artemisia expand and Betula shrubs decline between 11 and $10{ }^{14} \mathrm{C}$ ka BP (Pisaric et al., 2001).

\subsection{Climate variability during the Holocene}

At the Vidrino Site a spread of shrubs alders (Zone 5) stands for a warming at the base of the Holocene. There is no direct radiocarbon date from this zone. However it must be in between the levels dated with $9.9 \mathrm{cal} \mathrm{ka} \mathrm{(Boreal)} \mathrm{and} 12.3 \mathrm{cal}$ ka BP from the YD. As to the existence of the Preboreal we get some confidence because similar vegetation data, though slightly older but not assigned to a particular stage have already been reported from sites adjacent to Lake Baikal. From two outcrops on the shore of Chivyrkuy Bay, Kataoka et al. (2003) and Bezrukova et al. (1996) reported on shrub alders which show a maximum extension between ca. $10.8-9.5{ }^{14} \mathrm{C}$ ka BP. Similarly Andreev et al., (1997) reported from S Yakutien outcrops that after the YD like event high abundance of shrub alders was observed between 10.6 and $9{ }^{14} \mathrm{C}$ ka BP. As the ${ }^{14} \mathrm{C}$ data of the previously published records have been extracted on bulk TOC some slight bias towards older ages must be considered. However, we have to admit that the observed double peak of Duschekia fructicosa remains a rather unique feature restricted to the Vidrino Site. In previous cores as well as in the two other studied sites from the S and NE Lake Baikal this particular features is hardly to find, given the lower sedimentation rates. However, if we want to confirm this Preboreal pattern (distinct abundance maximum of Duschekia fructicosa) in future we need additional studies from new locations.

The regional spread of open forests after the Pleistocene-Holocene transition corresponds to distinctly improved thermal conditions, but at the same time the moisture index M (Figs. 7-9) is strongly decreasing. Early Holocene warming and drier conditions caused a spread of steppe vegetation in the $S$ (Figs. 5 and 6). This Tarasov et al. (2002) has reported a similar feature from Lake Kotokel, which is situated $125 \mathrm{~km} \mathrm{NE}$ of the Selenga Delta in a distance of $10 \mathrm{~km}$ from the shore of Lake Baikal. Furthermore steppe vegetation was dominant in the Mongolian Selenga catchment area until 9-8 ka BP, followed by a spread of forests with Betula and Pinus 
sylvestris (Gunin et al., 1999).

At about 10 ka BP (Figs. 8 and 9) fir (Abies sibirica) spread in the southern mountains whereas in NE the optimum development of fir forests began between 9.5 ka to 9 ka BP. From the NE of Lake Baikal, Kataoka et al. (2003) show a relatively late spread of fir, which contrasts with the early development of taiga with fir and Siberian pine in the S Baikal region (Bradbury et al., 1994, Bezrukova et al., 2000, Takahara et al., 2000).

During Holocene the most prominent event is the mid-Holocene expansion of Scots pine across the region. By this time moisture conditions have reached low values close to present day values while temperatures were probably warmest of the Holocene. Following the regional expansion of Scots pine, the T-index indicates a Holocene thermal optimum in the Baikal region from approximately 5.5 to $4.2 \mathrm{ka} \mathrm{BP}$ (Fig. 7-9). In E Siberia the climate optimum is recorded between ca. 6 and $5{ }^{14} \mathrm{C}$ ka BP (Velichko et al., 1997). However, mid-Holocene pollen records from the Baikal area are characterised by two spreading phases of Scots pine, which include a late major and the subsequent expansion of Scots pine. In the NE Baikal region these two events occurred ca. $6 \mathrm{ka} \mathrm{BP}$ and $5.5{ }^{14} \mathrm{C}$ ka BP respectively (Takahara et al., 2000; Kataoka et al., 2003; Tarasov et al., 2002). From the Chivyrkuy record a major spread of Scots pine has been reported for $6.1{ }^{14} \mathrm{C}$ ka BP when maximum concentrations is reached or at $5.4{ }^{14} \mathrm{C}$ ka BP when a relative maximum is shown (Kataoka et al., 2003). Pollen records from peat bogs at the S Baikal coast (Bezrukova et al., 2000; Takahara et al., 2000) and from Lake Chernoe in the SE of the Khamar-Daban Range (Tarasov et al., 2002) date the major spread of Scots pine to ca. $7{ }^{14} \mathrm{C}$ ka BP and its expansion to ca. $5.5{ }^{14} \mathrm{C}$ ka BP, respectively. Several spreading phases of Pinus sylvestris in the $S$ (since $10.1{ }^{14} \mathrm{C}$ ka BP) considerably preceded the late and gradual establishment of Scots pine taiga in the NE which occurred after 8.4 ka BP (Figs. 7 and 8). S-N differences in the spread of Scots pine are also evidenced in pollen records from the periphery of Lake Baikal (Bezrukova, 1999; Takahara et al., 2000). The regional variation in the progressive spread of Scots pine points to local differences in environmental and growing conditions, whereas the mid-Holocene expansion of Scots pine-dominated forests is recorded as a very pronounced coeval event across the Baikal region $\left(6.15{ }^{14} \mathrm{C} \mathrm{ka}\right.$ BP).

The Posolskoe record reveals a second thermal optimum at about 3.3-3 ka BP (Fig. 
9). This warming might be related to the Subboreal optimum, which is known to occur between 4.5 and $2.5 \mathrm{ka} \mathrm{BP}$. It has also been evidenced in a sedimentary record with diatoms and chrysophyte cysts near the Selenga Delta (Karabanov et al., 2000). Spruce declines indicating multiple coolings. The first occur around 8-7.2 ka BP (Fig. 9). It might be related to the GH-8.2 (8200 cal. yr BP) cooling event (Clarke et al., 2003; Björck et al., 1998; Walker et al., 1999). A second spruce decline includes the mid-Holocene cool interval occurring at 6.5-5.5 ka BP. Savina (1982) highlighted four periods with spruce (Picea obovata) maximum distribution and subsequent declines in the NE Baikal region including the Barguzin Range late glacial ("palaeoHolocene"), early mid-Holocene (7.9-7.7 ${ }^{14} \mathrm{C}$ ka BP), mid-Holocene $\left(5.5-5{ }^{14} \mathrm{C}\right.$ ka BP) and late Holocene (2.1-2 ${ }^{14} \mathrm{C}$ ka BP). From the NE and $\mathrm{S}$ mountains a cooling event, which can be related to the Atlantic-Subboreal transition occurs from 4.2 to $3.3 \mathrm{ka}$ BP. Still an other cooling event, which can be observed across the Baikal region may be related to the Subboreal-Subatlantic transition. It is dated 3-2.3 ka BP.

\subsection{Comparison with $\mathbf{N}$ Atlantic events}

Using an event stratigraphic approach the first warming during the Termination I corresponds to Greenland Interstadial GI-1 (14.7 - 12.65 cal ka BP), which follows the Greenland Stadial GS-2 from the GRIP ice core (Björck et al., 1998, Walker et al., 1999).. The punctuated increasing abundance of $B$. sect. Nanae/Fruticosae, during the last B/A -like event document three nearly synchronous cool and dry events most pronounced at Vidrino Site (Figs. 9). These events at approx. 14.2 ka BP, 13.9 ka BP and 13.2 cal ka BP can be tentatively correlated with cooler intervals recorded within Greenland isotope Interstadial GI-1 (Walker et al., 1999). The end of the Salix maximum distribution (Figs. 4-6) might be related to sub-stadial GI-1b, whereas an interval prior to the regional spread of spruces may correspond to a cooler period within sub-interstadial GI-1c and relates to the Older Dryas. Finally, the spread of forest-steppe at the spruce decline might be related to sub-stadial GI-1d, which reflects an intra-Alleröd cooling period. The pronounced vegetation changes during the Younger Dryas-like cooling event should then be time equivalent to the Greenland Stadial GS-1 (Walker et al., 1999). Some of these events have previously been traced from the diatom records of Baikal sediments (Prokopenko et al., 1999) 
The Vydrino record suggests a short cooling interval just after the transition to Holocene (Fig. 9), which might be related to the Preboreal Oscillation GH-11.2 (11, 2 cal ka BP) in the oxygen isotope records from Greenland ice cores (Björck et al., 1997; Walker et al., 1999).

In a first conclusion the pollen records provide evidence of pronounced warming at the transitions to interstadial like the $\mathrm{B} / \mathrm{A}$ and to the Holocene and show that climate changes in SE Siberia may correspond to the Dansgaard-Oeschger events 1 and 0 , respectively. Even a late Alleröd Dansgaard-Oeschger event A (Rahmstorf, 2003) might be observed in the Vydrino pollen record. It manifests as a slight spread of steppe taxa (Artemisia) within a spruce decline (lowermost part of LPASZ V-3b; Fig. $6)$.

The pattern of Holocene climate variation in the Baikal region (Fig. 9) is similar to the sequence of nine cool events in the subpolar North Atlantic, which are identified as intervals with increased deposition of ice-rafted debris and lowered sea-surface temperatures (Bond et al., 1997, 2001). In comparison to the North Atlantic record (Bond et al., 1997, 2001) major vegetational fluctuations and cooling events in the Baikal region (Fig. 7-9) may be correlated to (a) event 5 (ca. 8-6.5 ka BP), which comprises the 8.2 cal ka BP cooling event (Walker et al., 1999), (b) event 3 (ca. 4-3.5 ka BP) at the Atlantic-Subboreal transition, which also marks the end of the Holocene thermal optimum in northern China soil-loess records (Chen et al., 2003; Wu, Liu, 2004), (c) event 2 (ca. 3.2-2.5 ka BP) or the Subboreal-Subatlantic transition (van Geel, Renssen, 1998; Karabanov et al., 2000). According to this tentative correlation the pronounced mid-Holocene cooling in the Baikal region preceeded event 4 in the North Atlantic, whereas only moderate vegetational and climatic fluctuations during the late Mid-Holocene thermal optimum correspond to cooling event 4 which in the subpolar North Atlantic is strongly expressed.

Despite this major difference the recorded climate variability and the sequence of cool intervals in the Baikal region show high similarity to the North Atlantic events. Based on the age models the pollen data show that at least four large-scale climatic shifts affected the regional vegetation in the Baikal region and advocate for teleconnections as indicated by Holocene-cooling events recorded in the North Atlantic region which had an impact across northern Eurasia. 


\section{Conclusion}

These new pollen records from Lake Baikal are an excellent source for a detail reconstruction of changes in the regional vegetation and climate since the Late Glacial. Obtained results help to refine previously published pollen-based environmental reconstructions from the Baikal region and reliable age models facilitate correlation of reconstructed changes with synchronous events recognized elsewhere. An attempt to quantify observed changes in the pollen records in terms of changes in temperature ad humidity will be a matter of the authors' future work.

\section{Acknowledgement}

We are very grateful to Prof. Levi, Inst. Earth Crust Irkutsk, who introduced us into the vegetation during an excellent field trip. The work of Andrey Andreev and an anonymous reviewer who helped to improve this manuscript is gratefully acknowledged. This work was partially financed by the EU-project CONTINENT, Contract no. EVK2-2000-00057. 


\section{References}

Anderson, P.M., Lozhkin, A.V., Brubaker, L.B., 2002. Implications of a 24,000-yr palynological record for a Younger Dryas cooling and for boreal forest development in northeastern Siberia. Quaternary Research 57(3), 325-333. Andreev, A.A., Klimanov, V.A., Sulerzhitsky, L.D., 1997. Younger Dryas Pollen Records from central and southern Yakutia. Quaternary International 41-42, 111-117.

Andreev, A.A., Tarasov, P.E., Siegert, C., Ebel, T., Klimanov, V.A., Melles, M., Bobrov, A.A., Dereviagin, A.Yu., Lubinski, D.J., Hubberten H.-W., 2003. Late Pleistocene and Holocene vegetation and climate on the northern Taymyr Peninsula, Arctic Russia. Boreas 32, 484-505.

Belov, A.V. (Ed.), 1972. Vegetation of the south of East Siberia, 1:1500 000. Academy of Sciences of the USSR, Siberian Branch. Main Agency of Geodesy and Cartography at the Council of Ministers of the USSR, Moscow, 4 map sheets with legend (in Russian).

Belova, V.A., 1985. Vegetation and climate of the late Cenozoic in southern East Siberia. Nauka, Novosibirsk, 160 pp. (in Russian).

Beug, H.-J., 1961. Leitfaden der Pollenbestimmung. Gustav Fischer Verlag. Stuttgart. $63 \mathrm{pp}$.

Bezrukova, E.V., 1998. Palynology of late glacial and Holocene sediments of Lake Baikal. Geography and Natural Resources 3, 54-61 (in Russian).

Bezrukova, E.V., 1999. Palaeogeography of Pribaikalia during Lateglacial and Holocene. Nauka, Novosibirsk, 129 pp. (in Russian).

Bezrukova, E.V., Mats, V.D., Letunova, P.P., Nakamura, T., Fuji, S., 1996. Holocene peat bogs in Prebaikalia as an object of paleoclimatic reconstructions. Geologiya i Geofizika 37(12), 78-92 (in Russian, with English Abstr.).

Bezrukova, E.V., Krivonogov, S.K., Takahara, H., Vershinin, K.E., Miyoshi, N., Nakamura, T., Abzaeva, A.A., Morita, Y., Kawamuro, K., Shinomiya, T., Krapivina, S.M., 2000. Chronology of the late Pleistocene and Holocene history on the southeastern coast of Lake Baikal based on Dulikha core data. In: Baganov, E.A., Derebyanko, A.P., Zykin, V.S., Markin, S.V. (Eds.), Problems in reconstructing climate and environmental conditions in Siberia during Holocene and Pleistocene. Institute of Archaeology and Ethnography, Russian Academy of Sciences, Siberian Branch, Novosibirsk, pp. 36-47 (in Russian). 
Birks, H.J.B., 1968. The identification of Betula nana pollen. New Phytologist 67, 309314.

Birks, H.J.B., Birks, H.H., 1980. Quaternary Palaeoecology. Edward Arnold, London, $289 \mathrm{pp}$.

Björck, S., Walker, M.J.C., Cwynar, L.C., Johnsen, S., Knudsen, K.-L., Lowe, J.J., Wohlfarth, B., INTIMATE Members, 1998. An event stratigraphy for the Last Termination in the North Atlantic region based on the Greenland ice-core record: a proposal by the INTIMATE group. Journal of Quaternary Science 13(4), 283-292.

Blackmore, S., Steinmann, J.A.J., Hoen, P.P., Punt, W., 2003. Betulaceae and Corylaceae. Review of Palaeobotany and Palynology 123, 71-98.

Bond, G., Showers, W., Cheseby, M., Lotti, R., Almasi, P., deMenocal, P., Priore, P., Cullen, H., Hajdas, I., Bonani, G., 1997. A Pervasive Millennial-Scale Cycle in North Atlantic Holocene and Glacial Climates. Science 278 (5341), 1257-1266. Bond, G., Kromer, B., Beer, J., Muscheler, R., Evans, M.N., Showers, W., Hoffmann, S., Lotti-Bond, R., Hajdas, I., Bonani, G., 2001. Persistent Solar Influence on North Atlantic Climate During the Holocene. Science 294 (5549), 2130-2136. Bradbury, J.P., Bezrukova, E.V., Chernyaeva, G.P., Colman, S.M., Khursevich, G., King, J.W., Likoshway, Ye.V., 1994. A synthesis of post-glacial diatom records from Lake Baikal. Journal of Paleolimnology 10, 213-252.

\section{Charlet et al. this issue}

Chen, C.T.A., Lan, H.C., Lou J.Y., Chen, Y.C., 2003. The Dry Holocene Megathermal in Inner Mongolia. Palaeogeography, Palaeoclimatology, Palaeoecology 193, 181-200.

Colman, S.M., Jones, G.A., Rubin, M., King, J.W., Peck, J.A., Orem, W.H., 1996. AMS radiocarbon analyses from Lake Baikal, Siberia: Challenges of dating sediments from a large, oligotrophic lake. Quaternary Science Reviews 15(7), 669-684.

Cwynar, L.E., Burden, E., McAndrews, J.H., 1979. An inexpensive sieving method for concentrating pollen and spores from fine-grained sediments. Canadian Journal of Earth Sciences 16, 1115-1120.

deMenocal, P., Ortiz, J., Guilderson, T., Sarnthein, M., 2000. Coherent High- and Low-Latitude Climate Variability During the Holocene Warm Period. Science 288(5474), 2198-2202. 
Demory, F., N.R. Novaczyk, A. Witt and H. Oberhänsli . (2004)

High-resolution magnetostratigraphy of late Quaternary sediments from Lake Baikal,

Siberia: timing of intracontinental paleoclimatic responses

Fægri, K., Kaland, P.E., Krzywinski, K., 1989. Textbook of pollen analysis. 4th

edition. John Wiley \& Sons, Chichester-New York-Brisbane-Toronto-Singapore, $328 \mathrm{pp}$.

Fagel, N., L. Y. Alleman, L. Granina, F. Hatert, E. Bozso, R. Cloots, L. André

Vivianite formation and distribution in Lake Baikal sediments

Fowell, S.J., Hansen, B.C.S., Peck, J.A., Khosbayar, P., Ganbold, E., 2003. Mid to late Holocene climate evolution of the Lake Telmen Basin, North Central Mongolia, based on palynological data. Quaternary Research 59, 353-363.

\section{Francus, 1999.}

Gaillard, M.-J., 1983. On the occurrence of Betula nana L. pollen grains in the LateGlacial deposits of Lobsigensee (Swiss Plateau). Studies in the Late Quaternary of Lobsigensee 2. Revue de Paléobiologie 2(2), 181-188.

Galaziy, G.I. (Ed.), 1993. Baikal Atlas. Federal Agency for Geodesy and Cartography of Russia, Moscow, 160 pp. (in Russian).

Granina, G.T., Votyakova, N.E., 1981. Objects of investigation and classification of vegetation. In: Galaziy, G.I., Beideman, I.N. (Eds.), Vegetation ecology of the Selenga River delta. Nauka, Novosibirsk, pp. 56-113 (in Russian).

Granina, L., 1992. Ferromanganese formations in Lake Baikal: Formation conditions, composition, distribution. In: Horie, S. (Ed.), IPPCCE Newsletter (Universitätsverlag Wagner, Innsbruck) 6, pp. 39-47.

Grichuk, V.P., 1984. Late Pleistocene vegetation history. In: Velichko A.A., Wright, H.E., Barnosky, C.W. (Eds.), Late Quaternary environments of the Soviet Union. University of Minnesota Press, Minneapolis, pp. 155-178.

Grimm, E.C., 1987. A Fortran 77 program for stratigraphically constrained cluster analysis by the method of incremental sum of squares. Computers and Geosciences 13, 13-35.

Gunin, P.D., Vostokova, E.A., Dorofeyuk, N.I., Tarasov, P.E., Black, C.C., 1999. Vegetation Dynamics of Mongolia. Kluwer, Dordrecht-Boston-London, 238 pp. Horiuchi, K., Minoura, K., Hoshino, K., Oda, T., Nakamura, T., Kawai, T., 2000. Palaeoenvironmental history of Lake Baikal during the last 23000 years. 
Palaeogeography, Palaeoclimatology, Palaeoecology 157(1-2), 95-108.

Karabanov, E.B. 1982. The role of suspensional flows and under-water canyons in

the Baikal sediment formation. In: Belova, V.A., Lut, B.F. et al. (Eds.), Late

Cainozoic history of the lakes in the USSR. Nauka, Novosibirsk, pp. 30-38 (in Russian).

Karabanov, E.B., Prokopenko, A.A., Williams, D.F., Khursevich, G.K., 2000. A new record of Holocene climate change from the bottom sediments of Lake Baikal. Palaeogeography, Palaeoclimatology, Palaeoecology 156(3-4), 211-224.

Kataoka, H., Takahara, H., Krivonogov, S.K., Bezrukova, E.V., Orlova, L., Kropivina, S., Miyoshi, N., Kawamuro, K., 2003. Pollen Record from the Chivyrkui Bay Outcrop on the Eastern Shore of Lake Baikal since the Late Glacial. In: Kashiwaya, K. (Ed.), Long Continental Record from Lake Baikal. SpringerVerlag, Tokyo, pp. 207-218.

Khotinsky, N.A., 1984. Holocene Vegetation History. In: Velichko A.A., Wright, H.E., Barnosky, C.W. (Eds.), Late Quaternary environments of the Soviet Union. University of Minnesota Press, Minneapolis, pp. 179-200.

Kilian, M.R., van der Plicht, J., van Geel, B., Goslar, T., 2002. Problematic ${ }^{14} \mathrm{C}-\mathrm{AMS}$ dates of pollen concentrates from Lake Gosciaz (Poland). Quaternary International 88(1), 21-26.

Kögler, F.C., 1963. Das Kastenlot. Meyniana (Kiel) 13, 1-7.

Ladeyshchikov, N.I., 1975. Seasonal meteorological processes and climatic regionalisation. In: Galaziy, G. I., Parmuzin, Yu. P. (Eds.), Dynamics of the Baikal Depression. Trudy Limnologicheskogo Instituta (Nauka, Novosibirsk) 21(41), pp. 14-43 (in Russian).

Levi, K., Miroshnichenko, A.I., San'kov, V.A., Babushkin, S.M., Larkin, G.V., Badardinov, A.A., Wong, H.K., Colman, S., Delvaux, D., 1997. Active Faults of the Baikal Depression. Bull. Centre Rech. Elf Explor. Prod. 21(2), 399-434.

Litt, T., Stebich, M., 1999. Bio- and chronostratigraphy of the lateglacial in the Eifel region, Germany. Quaternary International 61, 5-16.

Lut, B.F., 1978. Pribaikal Geomorphology of the Lake Baikal Depression. Trudy Limnologicheskogo Instituta (Nauka, Novosibirsk) 26(46), 214 pp. (in Russian). Mats, V.D., 1993. The structure and development of the Baikal rift depression. EarthScience Reviews 34, 81-118. 
Meischner, D., Rumohr, J., 1974. A Light-weight, High-momentum Gravity Corer for Subaqueous Sediments. Senckenbergiana marit. (Frankfurt am Main) 6 (1), 105-117.

Molozhnikov, V.N., 1981. Geographical setting and natural conditions in the Selenga delta. In: Galaziy, G.I., Beideman, I.N. (Eds.), Vegetation ecology of the Selenga river delta. Nauka, Novosibirsk, pp. 4-7 (in Russian).

Molozhnikov, V.N., Molozhnikova, V.V., 1988. A study of the vegetation in the surroundings of Baikalsk. In: Galaziy, G.I. (Ed.), Vegetation of the KhamarDaban Range. Nauka, Novosibirsk, pp. 5-31 (in Russian).

Monserud, R.A., Tchebakova, N.M., Denissenko, O.V., 1998. Reconstruction of the mid-Holocene palaeoclimate of Siberia using a bioclimatic vegetation model. Palaeogeography, Palaeoclimatology, Palaeoecology 139, 15-36.

PALE Steering Committee, 1994. Suggested protocol for extracting pollen and spores from low-carbon lacustrine sediments. Appendix in: Research Protocols for PALE - Paleoclimates of Arctic Lakes and Estuaries, issued 29 June 1993. PAGES Workshop Report, Series 94-1, pp. 49-53.

Piotrowska, N., Bluszcz, A., Demske, D., Granoszewski, W., Heumann, G., 2004. Extraction and AMS radiocarbon dating of pollen from Lake Baikal sediments. Radiocarbon 46(2).

Pisaric, M.F.J., MacDonald, G.M., Velichko, A.A., Cwynar, L.C., 2001. The Lateglacial and Postglacial vegetation history of the northwestern limits of Beringia, based on pollen, stomate and tree stump evidence. Quaternary Science Reviews 20, 235-245.

Prokopenko, A.A., Williams, D.F., Karabanov, E.B., Khursevich, G.K., 1999.

Response of Lake Baikal ecosystem to climate forcing and $p \mathrm{CO}_{2}$ change over the last glacial/interglacial transition. Earth and Planetary Science Letters 172(3-4), 239-253.

Prokopenko, A.A., 2000. Challenges in constructing the age model for the Lake Baikal cores during the last glacial/interglacial transition: the response to M.A. Grachev. Earth and Planetary Science Letters 181, 267-270.

Rahmstorf, S., 2003. Timing of abrupt climate change: A precise clock. Geophysical Research Letters 30(10), 1510, doi:10.1029/2003GL017115.

Savina, L.N., 1982. Trends of the coastal landscape development of Baikal (on paleogeographical data). In: Belova, V.A., Lut, B.F. et al. (Eds.), Late Cainozoic 
history of the lakes in the USSR. Nauka, Novosibirsk, pp. $42-52$ (in Russian). Stockmarr, J., 1971. Tablets with spores used in absolute pollen analysis. Pollen Spores 13, 614-621.

Takahara, H., Krivonogov, S.K., Bezrukova, E.V., Miyoshi, N., Morita, Y., Nakamura, T., Hase, Y., Shinomiya, Y., Kawamuro, K., 2000. Vegetation history of the southeastern and eastern coasts of Lake Baikal from bog sediments since the last interstade. In: Minoura, K. (Ed.), Lake Baikal: A Mirror in Time and Space for Understanding Global Change Processes. Elsevier, Amsterdam, pp. 108118.

Tarasov, P.E., Webb, T., Andreev, A.A., Afanaseva, N.B., Berezina, N.A., Bezusko, L.G., Blyakharchuk, T.A., Bolikhovskaya, N.S., Cheddadi, R., Chernavskaya, M.M., Chernova, G.M., Dorofeyuk, N.I., Dirksen, V.G., Elina, G.A., Filimonova, L.V., Glebov, F.Z., Guiot, J., Gunova, V.S., Harrison, S.P., Jolly, D., Khomutova, V.I., Kvavadze, E.V., Osipova, I.R., Panova, N.K., Prentice, I.C., Saarse, L., Sevastyanov, D.V., Volkova, V.S., Zernitskaya, V.P., 1998. Present-day and mid-Holocene biomes reconstructed from pollen and plant macrofossil data from the Former Soviet Union and Mongolia. Journal of Biogeography 25, 10291054.

Tarasov, P.E., Volkova, V.S., Webb, T., Guiot, J., Andreev, A.A., Bezusko, L.G., Bezusko, T.V., Bykova, G.V., Dorofeyuk, N.I., Kvavadze, B.V., Osipova, I.M., Panova, N.K., Sevastyanov, D.V., 2000. Last glacial maximum biomes reconstructed from pollen and plant macrofossil data from northern Eurasia. Journal of Biogeography 27, 609-620.

Tarasov, P.E., Dorofeyuk, N.I., Vipper, P.B., 2002. The dynamics of vegetation in Buryatia during the Holocene. Stratigrafiya, Geologicheskaya korrelatsiya 10(1), 94-103 (in Russian).

Tyulina, L.N., 1976. Moist near-Baikal type of vegetation zonation. Trudy Limnologicheskogo Instituta (Nauka, Novosibirsk) 23(43), 320 pp. (in Russian). van Geel, B., Renssen, H., 1998. Abrupt Climate Change around 2,650 BP in NorthWest Europe: Evidence for Climatic Teleconnections and a Tentative explanation. In: Issar, A.S., Brown, N. (Eds.), Water, Environment and Society in Times of Climatic Change. Kluwer, Amsterdam, pp. 21-41.

Velichko, A.A., Andreev, A.A., Klimanov, V.A., 1997. Climate and vegetation dynamics in the tundra and forest zone during the Late Glacial and Holocene. 
Quaternary International 41/42, 71-96.

Walker, M.J.C., Björck, S., Lowe, J.J., Cwynar, L.C., Johnsen, S., Knudsen, K.-L., Wohlfarth, B., INTIMATE group, 1999. Isotopic 'events' in the GRIP ice core: a stratotype for the Late Pleistocene. Quaternary Science Reviews 18, 11431150.

Walter, H., 1974. Die Vegetation Osteuropas, Nord- und Zentralasiens. Gustav Fischer Verlag, Stuttgart, $452 \mathrm{pp}$.

White, J.M., Ager, T.A., Adam, D.P., Leopold, E.B., Liu, G., Jetté, H., Schweger, C.E., 1997. An 18 million year record of vegetation and climate change in northwestern Canada and Alaska: tectonic and global climate correlates. Palaeogeography Palaeoclimatology, Palaeoecology 130, 293-306.

Whitlock, C., Bartlein, P.J., 1997. Vegetation and climate change in northwest America during the past $125 \mathrm{kyr}$. Nature 388, 57-61.

Wu Wenxiang, Liu Tungsheng, 2004. Possible role of the "Holocene Event 3" on the collapse of Neolithic Cultures around the Central Plain of China. Quaternary International 117, 153-166. 
Table 1. Meteorological data for three stations situated close to the shore of Lake Baikal and in vicinity of the three coring sites (Fig. 1) (source: Ladeyshchikov, 1975).

\begin{tabular}{lccc}
\hline Region & $\begin{array}{c}\text { west of } \\
\text { Barguzin Range }\end{array}$ & $\begin{array}{c}\text { south of } \\
\text { Selenga delta }\end{array}$ & $\begin{array}{c}\text { north of } \\
\text { Khamar-Daban Range }\end{array}$ \\
\hline Station & Sosnowka & Istok & Vydrino \\
Elevation a.s.l. & $460 \mathrm{~m}$ & $466 \mathrm{~m}$ & $474 \mathrm{~m}$ \\
\hline MMT $^{\mathrm{a}}$ January $\left({ }^{\circ} \mathrm{C}\right)$ & -23.4 & -19.4 & -18.7 \\
MMT $^{\mathrm{a}}$ July $\left({ }^{\circ} \mathrm{C}\right)$ & +10.4 & +14.0 & +15.4 \\
MAT $^{\mathrm{b}}\left({ }^{\circ} \mathrm{C}\right)$ & -4.5 & -1.6 & -0.9 \\
\hline Precipitation (mm) & 370 & 336 & 828 \\
- summer (April-Oct.) & 149 & 62 & 273 \\
- winter (Oct.-March) & 519 & 398 & 1101 \\
MAP $^{\mathrm{c}}$ (mm) & ${ }^{\mathrm{a}}$ MMT - mean monthly temperature & ${ }^{\mathrm{b}}$ MAT - mean annual temperature & ${ }^{\mathrm{c}}$ MAP - mean annual precipitation
\end{tabular}


Table 2. Pollen subsums used for the calculation of vegetational indices, which show relative changes in major vegetation types related to palaeoclimatic conditions. Pollen types assigned to steppe and boreo-alpine vegetation (S1 and S7) comprise non-arboreal pollen (NAP), while the remaining groups (S2 to S6) only include arboreal pollen (AP). Moisture index M and temperature index $\mathrm{T}$ are based on the square-root of ratios between pollen subsums.

Subsum Dry vegetation types Pollen types included

S1 steppe tax

Artemisia, Asteraceae, Chenopodiaceae, Ephedra, Poaceae , Ranunculaceae undiff., Thalictrum, Rosaceae undiff., Potentilla-type, Sanguisorba officinalis, Allium, Apiaceae, Boraginaceae, Brassicaceae, Caryophyllaceae, Fabaceae, Galium-type, Lamiaceae, Papaveraceae, Plantago, Plumbaginaceae, Sedum-type, Polygonum aviculare-type and selected further NAP

S2 birch forest-steppe, birch Betula sect. Albae, Ulmus (AP) subtaiga, Ulmus pumila

S3 light-needled taiga Larix, Pinus sylvestris-type, Juniperus (AP)

Moist vegetation types

S4 $\quad$ dark-needled taiga $\quad$ Picea obovata, Pinus sibirica-type, Abies, Sorbus, Sambucus, Lonicera (AP)

S5 subalpine shrubs

S6 other shrubs Duschekia, Rhododendron (AP)

S7 boreo-alpine taxa Salix, Betula sect. Nanae/Fruticosae (AP) Ericales, Saxifraga, Dryas, Pedicularis, Gentianaceae, Cyperaceae, Polygonum undiff., Rumex, Oxyria (NAP)

\begin{tabular}{lll} 
Index & Vegetational indices & Calculation \\
\hline $\mathrm{M}$ & moisture index & $\mathrm{M}=\mathrm{sqr}(\mathrm{R})$, where $\mathrm{R}=(\mathrm{S} 4+\mathrm{S} 5+\mathrm{S} 6+\mathrm{S} 7) /(\mathrm{S} 1+\mathrm{S} 2+\mathrm{S} 3)$ \\
$\mathrm{T}$ & temperature index & $\mathrm{T}=\mathrm{sqr}(\mathrm{R})$, where $\mathrm{R}=(\mathrm{S} 2+\mathrm{S} 3+\mathrm{S} 4+\mathrm{S} 6) /(\mathrm{S} 5+\mathrm{S} 7)$ \\
\cline { 2 - 3 }
\end{tabular}


Table 3. AMS ${ }^{14} \mathrm{C}$ datings of pollen concentrates. Volumes of prepared sediment samples ranged between 20 and $160 \mathrm{~cm}^{3}$.

\begin{tabular}{|c|c|c|}
\hline $\begin{array}{c}\text { Sample } \\
\text { code }\end{array}$ & $\begin{array}{c}\text { Depth } \\
{[\mathrm{cm}]}\end{array}$ & 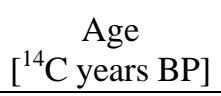 \\
\hline \multicolumn{3}{|c|}{ Continent Ridge, core CON01-603-5 ${ }^{a}$} \\
\hline GdA-247 & $0-4$ & $1235 \pm 25$ \\
\hline GdA-248 & $18-22$ & $4060 \pm 30$ \\
\hline GdA-249 & $24-28$ & $4955 \pm 30$ \\
\hline GdA-250 & $32-36$ & $5335 \pm 30$ \\
\hline GdA-251 & $39-43$ & $6630 \pm 35$ \\
\hline GdA-252 & $54-58$ & $8570 \pm 40$ \\
\hline GdA-253 & $60-64$ & $8690 \pm 50$ \\
\hline GdA-257 & $70-76$ & $10250 \pm 50$ \\
\hline GdA-258 & $78-84$ & $11090 \pm 80$ \\
\hline GdA-259 & $86-92$ & $11960 \pm 50$ \\
\hline \multicolumn{3}{|c|}{ Posolskoe High, core CON01-606-3 $^{\text {a }}$} \\
\hline GdA-217 & $29-32$ & $2425 \pm 40$ \\
\hline GdA-219 & $44-46$ & $3200 \pm 45$ \\
\hline GdA-231 & $56-57$ & $3850 \pm 35$ \\
\hline GdA-232 & $57-58$ & $3985 \pm 40$ \\
\hline GdA-220 & $66-68$ & $5520 \pm 45$ \\
\hline GdA-225 & $80-81$ & $9350 \pm 60$ \\
\hline GdA-226 & $81-82$ & $11710 \pm 70$ \\
\hline GdA-233 & $84-86$ & $11320 \pm 110$ \\
\hline GdA-218 & $89-93$ & $12200 \pm 70$ \\
\hline GdA-224 & $100-104$ & $15250 \pm 210$ \\
\hline GdA-223 & $108-112$ & $15040 \pm 90$ \\
\hline GdA-222 & $116-124$ & $20920 \pm 160$ \\
\hline \multicolumn{3}{|c|}{ Vydrino Shoulder, core CON01-605-5 ${ }^{\text {a }}$} \\
\hline GdA-260 & $0-4$ & $1950 \pm 35$ \\
\hline GdA-261 & $20-24$ & $2375 \pm 25$ \\
\hline GdA-263 & $32-35$ & $2945 \pm 30$ \\
\hline GdA-264 & $56-59$ & $4530 \pm 40$ \\
\hline GdA-265 & $77-80$ & $5455 \pm 35$ \\
\hline GdA-266 & $89-92$ & $6170 \pm 40$ \\
\hline GdA-267 & $101-104$ & $6700 \pm 40$ \\
\hline GdA-268 & $121-124$ & $7760 \pm 40$ \\
\hline GdA-269 & $138-141$ & $8620 \pm 40$ \\
\hline GdA-271 & $145-148$ & $8750 \pm 50$ \\
\hline GdA-272 & 159-163 & $9470 \pm 50$ \\
\hline GdA-270 & $171.5-175.5$ & $10030 \pm 50$ \\
\hline \multicolumn{3}{|c|}{ Vydrino Shoulder, core CON01-605-3 } \\
\hline GdA-338 & $12-18$ & $8810 \pm 50$ \\
\hline GdA-339 & $48-56$ & $10340 \pm 60$ \\
\hline GdA-340 & $65-73$ & $10730 \pm 60$ \\
\hline GdA-341 & $90-98$ & $11820 \pm 70$ \\
\hline GdA-342 & $116-124$ & $13340 \pm 130$ \\
\hline
\end{tabular}

${ }^{\mathrm{a}}$ Data published in Piotrowska et al. (2004) 
Table 4. Correlation of local pollen assemblage zones (LPAZ) and subzones (LPASZ) for the three coring sites. The main subdivisions are delineated according to numerical zonation (solid horizontal lines). Further subdivisions were introduced by visual comparison between the records (broken lines). Ages are given in ${ }^{14} \mathrm{C}$ years BP and include extrapolated or inferred values (in brackets).

Pollenstratigraphic units in the upper $45 \mathrm{~cm}$ of Vydrino core CON01-605-3, which are not shown in the table, comprise: LPAZ V-8 (4-0 cm) Pinus sylvestris-type - P. sibirica-type - Betula sect. Albae, LPAZ V-7 (19-4 cm) Pinus sylvestris-type - Betula sect. Albae - P. sibirica-type - Abies, LPAZ V-6 (26-19 cm) Betula sect. Albae - B. sect. Nanae/Fruticosae - Pinus sibirica-type comprising LPASZ V-6b $(23-19 \mathrm{~cm})$ and V-6a $(26-23$ cm), LPAZ V-5 (45-26 cm) Duschekia fruticosa - Betula sect. Nanae/Fruticosae - Salix.

\begin{tabular}{|c|c|c|c|c|c|}
\hline \multicolumn{2}{|c|}{ Continent Ridge, CON01-603-5 } & \multicolumn{2}{|c|}{ Posolskoe High, CON01-606-3 } & \multicolumn{2}{|c|}{ Vydrino Shoulder, CON01-605-5/-3 } \\
\hline LPAZ: depth (cm) & LPASZ: depth (cm) & LPAZ: depth (cm) & LPASZ: depth (cm) & LPAZ: depth (cm) & LPASZ: depth (cm) \\
\hline Main pollen types & Age $\left({ }^{14} \mathrm{C} \mathrm{BP}\right.$, unadj. $)$ & Main pollen types & Age $\left({ }^{14} \mathrm{C}\right.$ BP, unadj. $)$ & Main pollen types & Age $\left({ }^{14} \mathrm{C} \mathrm{BP}\right.$, unadj. $)$ \\
\hline \multirow{3}{*}{$\begin{array}{l}\text { C-8: } \mathbf{7 . 5 - 0} \\
\text { Pinus sylvestris- } \\
\text { type, P. sibirica- } \\
\text { type, Larix }\end{array}$} & C-8b: 3.5-0 & \multirow{6}{*}{$\begin{array}{l}\text { P-7: 44.75-0 } \\
\text { Pinus sylvestris-type, } \\
\text { P. sibirica-type, } \\
\text { Artemisia, Betula } \\
\text { sect. Nanael } \\
\text { Fruticosae }\end{array}$} & P-7d: 9.75-0 & \multirow{13}{*}{$\begin{array}{l}\text { VH-6: 90.75-0 } \\
\text { Pinus sylvestris-type, } \\
\text { P. sibirica-type, } \\
\text { Betula } \text { sect. Albae }\end{array}$} & VH-6e: $5.75-0$ \\
\hline & $930-1470$ & & $(675-1230)$ & & $960-1310$ \\
\hline & C-8a: 7.5-3.5 & & P-7c: 29.75-9.75 & & VH-6d: 47.75-5.75 \\
\hline C-7: 16-7.5 & C-7b: $12.5-7.5$ & & & & VH-6d-3 \\
\hline \multirow{3}{*}{$\begin{array}{l}\text { Pinus sylvestris- } \\
\text { type, Larix, } \\
\text { Artemisia }\end{array}$} & $2100-2870$ & & $\begin{array}{l}\text { P-7b: 38.75-29.75 } \\
2360-2880\end{array}$ & & $\begin{array}{l}\mathbf{V H}-\mathbf{6 d}-\mathbf{2}: \\
2420-\end{array}$ \\
\hline & $\begin{array}{l}\text { C-7a: 16-12.5 } \\
2870-3420\end{array}$ & & $\begin{array}{l}\text { P-7a: } 44.75-38.75 \\
2880-3220\end{array}$ & & 3160 \\
\hline & & \multirow{7}{*}{$\begin{array}{l}\text { Pinus sylvestris-type, } \\
P . \text { sibirica-type }\end{array}$} & $\begin{array}{l}\text { P-6c: 50.75-44.75 } \\
3220-3560\end{array}$ & & $\begin{array}{l}\text { VH-6d-1: } \\
3160-\end{array}$ \\
\hline \multirow{6}{*}{$\begin{array}{l}\text { C-6: } \mathbf{3 8 . 2 5 - 1 6} \\
\text { Pinus sylvestris- } \\
\text { type, P. sibirica- } \\
\text { type, Picea obovata, } \\
\text { Larix }\end{array}$} & \multirow{4}{*}{$\begin{array}{l}\text { C-6b: } \mathbf{2 7 . 2 5 - 1 6} \\
3420-4920\end{array}$} & & P-6b: 59.75-50.75 & & 3910 \\
\hline & & & $3560-4350$ & & VH-6c: 59.75-47.75 \\
\hline & & & P-6a: 69.75-59.75 & & $3910-4650$ \\
\hline & & & $4350-6100$ & & VH-6b: 80.75-59 \\
\hline & \multirow{2}{*}{$\begin{array}{l}\text { C-6a: 38.25-27.25 } \\
4920-6190\end{array}$} & & & & $4650-5660$ \\
\hline & & & & & $\begin{array}{l}\text { VH-6a: 90.75-80.75 } \\
5660-6140\end{array}$ \\
\hline \multirow{7}{*}{$\begin{array}{l}\text { C-5: 64.25-38.25 } \\
\text { Picea obovata, } \\
\text { Betula } \text { sect. Albae, } \\
\text { Pinus sibirica-type, } \\
\text { Abies sibirica, } \\
\text { Larix, B. sect. } \\
\text { Nanae +Fruticosae }\end{array}$} & \multirow{3}{*}{$\begin{array}{l}\text { C-5b: 43.25-38.25 } \\
6190-6760\end{array}$} & \multirow{4}{*}{$\begin{array}{l}\text { P-5: 80.75-69.75 } \\
\text { Betula sect. Albae, } \\
\text { Pinus sibirica-type, } \\
\text { P. sylvestris-type, B. } \\
\text { sect. Nanael } \\
\text { Fruticosae }\end{array}$} & P-5b: 76.75-69.75 & \multirow{7}{*}{$\begin{array}{l}\text { VH-5: 154.75-90.75 } \\
\text { Betula sect. Albae, } \\
\text { Pinus sibirica-type, } \\
\text { P. sylvestris-type, } \\
\text { Abies sibirica }\end{array}$} & VH-5e: $102.75-90.75$ \\
\hline & & & $(6100-7560)$ & & $6140-6710$ \\
\hline & & & & & $\begin{array}{l}\text { VH-5d: 121.75-102.75 } \\
6710-7630\end{array}$ \\
\hline & $\begin{array}{l}6760-9180 \\
\text { C-5a-2 to }-4\end{array}$ & & $\begin{array}{l}\text { P-5a: 80.75-76.75 } \\
(7560-8400)\end{array}$ & & $\begin{array}{l}\text { VH-5c: 137.75-121.75 } \\
7630-8390\end{array}$ \\
\hline & C-5a-1: & \multirow{10}{*}{$\begin{array}{l}\text { P-4: 95.75-80.75 } \\
\text { Betula } \text { sect. Nanael } \\
\text { Fruticosae, B. sect. } \\
\text { Albae, Artemisia, } \\
\text { Picea obovata }\end{array}$} & P-4b: 84.75-80.75 & & VH-5b: $144.75-137.75$ \\
\hline & $8380-$ & & $(8400-9200)$ & & $8390-8730$ \\
\hline & 9180 & & & & $\begin{array}{l}\text { VH-5a: 154.75-144.75 } \\
8730-9210\end{array}$ \\
\hline \multirow{7}{*}{$\begin{array}{l}\text { C-4: 77.25-64.25 } \\
\text { Betula sect. Albae, } \\
\text { Picea obovata, } \\
\text { Larix, B. sect. } \\
\text { Nanae+Fruticosae }\end{array}$} & C-4b: 72.25-64.25 & & P-4a: 95.75-84.75 & \multirow{7}{*}{$\begin{array}{l}\text { VH-4: 176.5-154.75 } \\
\text { and V-4: 68.5-45 } \\
\text { Betula } \text { sect. Nanael } \\
\text { Fruticosae, B. sect. } \\
\text { Albae, Picea obovata, } \\
\text { Poaceae, Duschekia } \\
\text { fruticosa }\end{array}$} & VH-4c: $162.75-154.75$ \\
\hline & $9180-10110$ & & $(9200-10700)$ & & $9210-9590$ \\
\hline & & & P-4a-2. & & VH-4b: 176.5-162.75 \\
\hline & & & $\begin{array}{l}\text { P-4a-2: } \\
(9200-\end{array}$ & & V-4b: $56.5-45$ \\
\hline & & & $10150)$ & & $9780-10310$ \\
\hline & C-4a: 77.25-72.25 & & P-4a-1: & & V-4a: $68.5-56.5$ \\
\hline & $10110-10680$ & & $\begin{array}{l}(10150- \\
10700)\end{array}$ & & $10310-10860$ \\
\hline \multirow{4}{*}{$\begin{array}{l}\text { C-3: 90.25-77.25 } \\
\text { Duschekia fruticosa, } \\
\text { Salix, Picea } \\
\text { obovata, Betula } \text { sect. } \\
\text { Nanae+Fruticosae }\end{array}$} & C-3b: 85.25-77.25 & \multirow{4}{*}{$\begin{array}{l}\text { P-3: 108.75-95.75 } \\
\text { Duschekia fruticosa, } \\
\text { Salix, Poaceae, } \\
\text { Betula sect. Nanael } \\
\text { Fruticosae, Picea } \\
\text { obovata }\end{array}$} & P-3b: 103.75-95.75 & \multirow{4}{*}{$\begin{array}{l}\text { V-3: 98.5-68.5 } \\
\text { Duschekia fruticosa, } \\
\text { Betula sect. Nanael } \\
\text { Fruticosae, Picea } \\
\text { obovata, Poaceae }\end{array}$} & V-3b: $90-68.5$ \\
\hline & $10680-11610$ & & $(10700-11600)$ & & $10860-11840$ \\
\hline & C-3a: 90.25-85.25 & & P-3a: 108.75-103.75 & & V-3a: $98.5-90$ \\
\hline & $11610-12180$ & & $(11600-12150)$ & & $11840-12230$ \\
\hline \multirow{3}{*}{$\begin{array}{l}\text { C-2: 101.25-90.25 } \\
\text { Salix, Duschekia } \\
\text { fruticosa, Betula } \\
\text { sect. Nanae } \\
+ \text { Fruticosae }\end{array}$} & C-2b: 97.25-90.25 & \multirow{3}{*}{$\begin{array}{l}\text { P-2: 116.75-108.75 } \\
\text { Salix, Betula } \text { sect. } \\
\text { Nanae/Fruticosae, } \\
\text { Artemisia, Poaceae }\end{array}$} & P-2b: 113.75-108.75 & \multirow{3}{*}{$\begin{array}{l}\text { V-2: 126.5-98.5 } \\
\text { Salix, Betula } \text { sect. } \\
\text { Nanae/ Fruticosae, } \\
\text { Duschekia fruticosa, } \\
\text { Poaceae }\end{array}$} & V-2b: 116.5-98.5 \\
\hline & $(12180-12990)$ & & $(12150-13000)$ & & $12230-13060$ \\
\hline & $\begin{array}{l}\text { C-2a: 101.25-97.25 } \\
(12990-13450)\end{array}$ & & $\begin{array}{l}\text { P-2a: 116.75-113.75 } \\
(13000-13500)\end{array}$ & & $\begin{array}{r}\text { V-2a: 126.5-116.5 } \\
13060-13520\end{array}$ \\
\hline \multirow{3}{*}{$\begin{array}{l}\text { C-1: 116-101.25 } \\
\text { Artemisia, } \\
\text { Asteraceae subgen. } \\
\text { Cichorioideae, } \\
\text { Cyperaceae }\end{array}$} & C-1b: 107.25-101.25 & & $(13500-14880)$ & V-1: 171-126.5 & V-1b: 141-126.5 \\
\hline & $(13450-14140)$ & Poaceae, Artemisia, & & Poaceae, Cyperaceae, & $(13520-14180)$ \\
\hline & $\begin{array}{l}\text { C-1a: 116-107.25 } \\
(14140-15 \text { 150) }\end{array}$ & $\begin{array}{l}\text { Cyperaceae, Betula } \\
\text { sect. Nanael } \\
\text { Fruticosae }\end{array}$ & & Artemisia & $\begin{array}{r}\text { V-1a: 171-141 } \\
(14180-15550)\end{array}$ \\
\hline
\end{tabular}




\section{Figure Captions}

Fig. 1. Map of the Lake Baikal region, southern East Siberia, with main mountain ranges and rivers. The three coring sites (dots) and nearby meteorological stations (triangles) are: Continent Ridge and station Sosnovka in the northeast, Posolskoe High and station Istok in the southeast, Vydrino Shoulder and station Vydrino in the south.

Fig. 2. Generalised diagrams showing altitudinal distribution ranges of major vegetation types in the northeastern and southern mountains of the Baikal region. (A) West-facing slopes of the Barguzin Range northeast of coring site Continent Ridge (based on Tyulina, 1976, Belov, 1972). (B) North-facing slopes of the Khamar-Daban Range south of coring site Vydrino Shoulder (based on Molozhnikov, 1981, Molozhnikov and Molozhnikova, 1988).

Fig. 3. Simplified palynological diagram with pollen zones of Kasten Core CON01-603-5 from Continent Ridge (black line: percentage data with 10x exaggeration) plotted vs depth. Additionally shown are pteridophyte spores, Sphagnum spores and non-siliceous algal remains. The subdivisions into pollen assemblage zones and subzones are numerically delineated. The black boxes indicate radiocarbon dated intervals. Empty boxes indicate samples with dead carbon. Calibrated AMS radiocarbon age are listed. (Piotowska et al., 1994). (Data available at: doi:10.1594/GFZ/ICDP/CON/2004....)

Fig. 4. Simplified palynological diagram with pollen zones of Kasten Core CON01-606-6 from Posolskoe High (black line: percentage data with 10x exaggeration) plotted vs depth. Additionally shown are pteridophyte spores, Sphagnum spores and non-siliceous algal remains. The black boxes indicate radiocarbon dated intervals. Empty boxes indicate dated samples with dead carbon. Calibrated AMS radiocarbon ages are listed (Piotowska et al., 1994). (Data available at: doi:10.1594/GFZ/ICDP/CON/2004....)

Fig. 5. Simplified palynological diagram with pollen zones for Kasten Core CON01-605-5 and Pilote Core CON01-605-3 from Vydrino Shoulder (black line: percentage data with 10x exaggeration) plotted vs depth. The black boxes indicate radiocarbon dated intervals. Calibrated AMS radiocarbon ages are listed. (Piotowska et al., 1994 together with recently dated samples from Core CON01-605-3). (Data available at: doi:10.1594/GFZ/ICDP/CON/2004....)

Fig. 6. Selected pollen records of Core CON01-603-5 from Continent Ridge plotted vs calibrated ages and stages and substages. The indices $\mathrm{M}$ and $\mathrm{T}$ indicate relative humidity and temperature variations as inferred from the pollen assembalges (see text).

Fig. 7. Selected pollen records of Core CON01-606-6 from Posolskoe High plotted vs calibrated ages, stages and substages. The indices $\mathrm{M}$ and $\mathrm{T}$ indicate relative humidity and temperature variations as inferred from the pollen assembalges (see text).

Fig. 8. Selected pollen records of Core CON01-605-5 and Pilote Core CON01-605-3 from Vydrino Shoulder plotted vs calibrated ages, stages and substages. The indices $\mathrm{M}$ and $\mathrm{T}$ indicate relative humidity and temperature variations as inferred from the pollen assembalges (see text). 


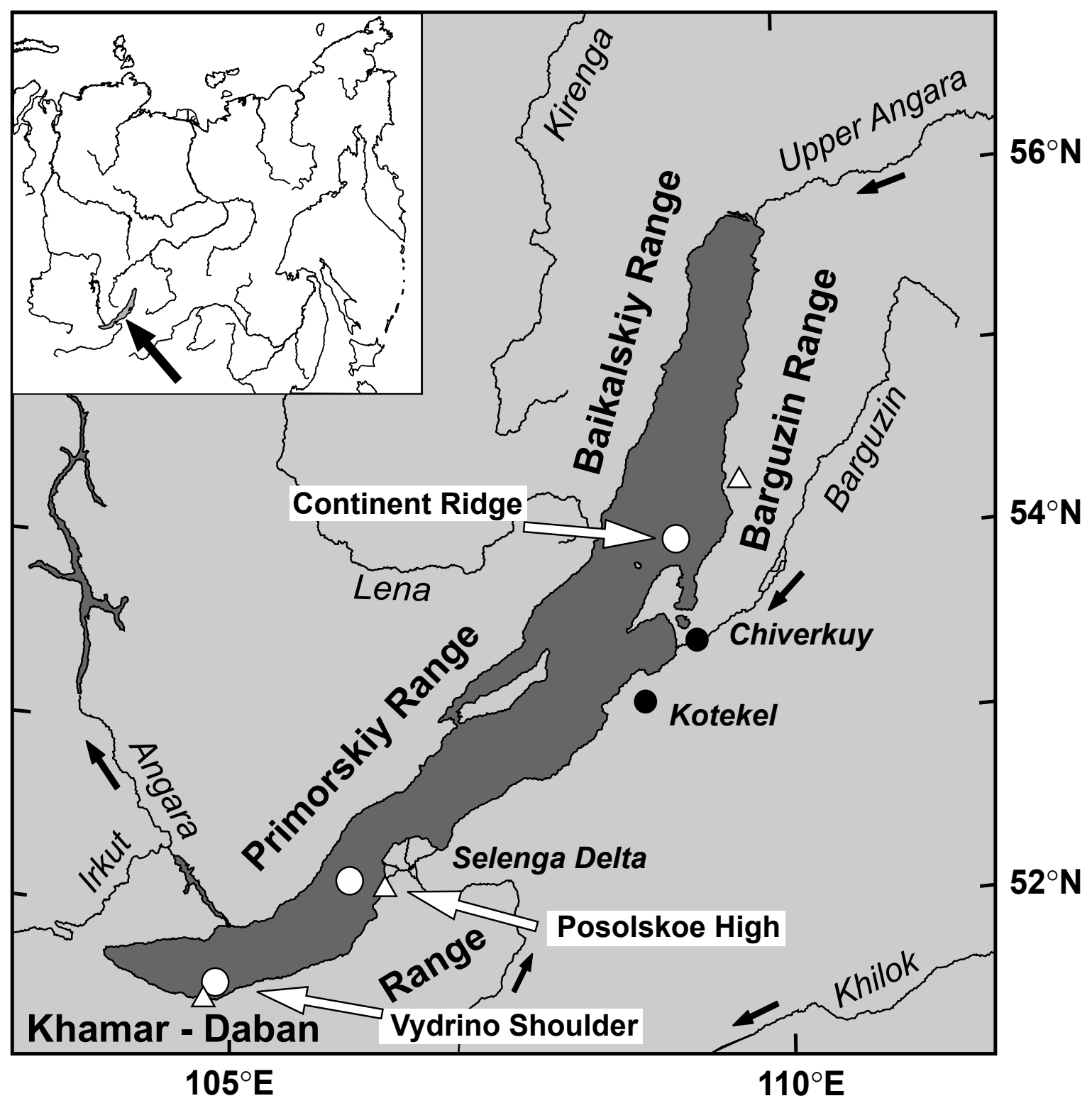

Demske-Fig.1 


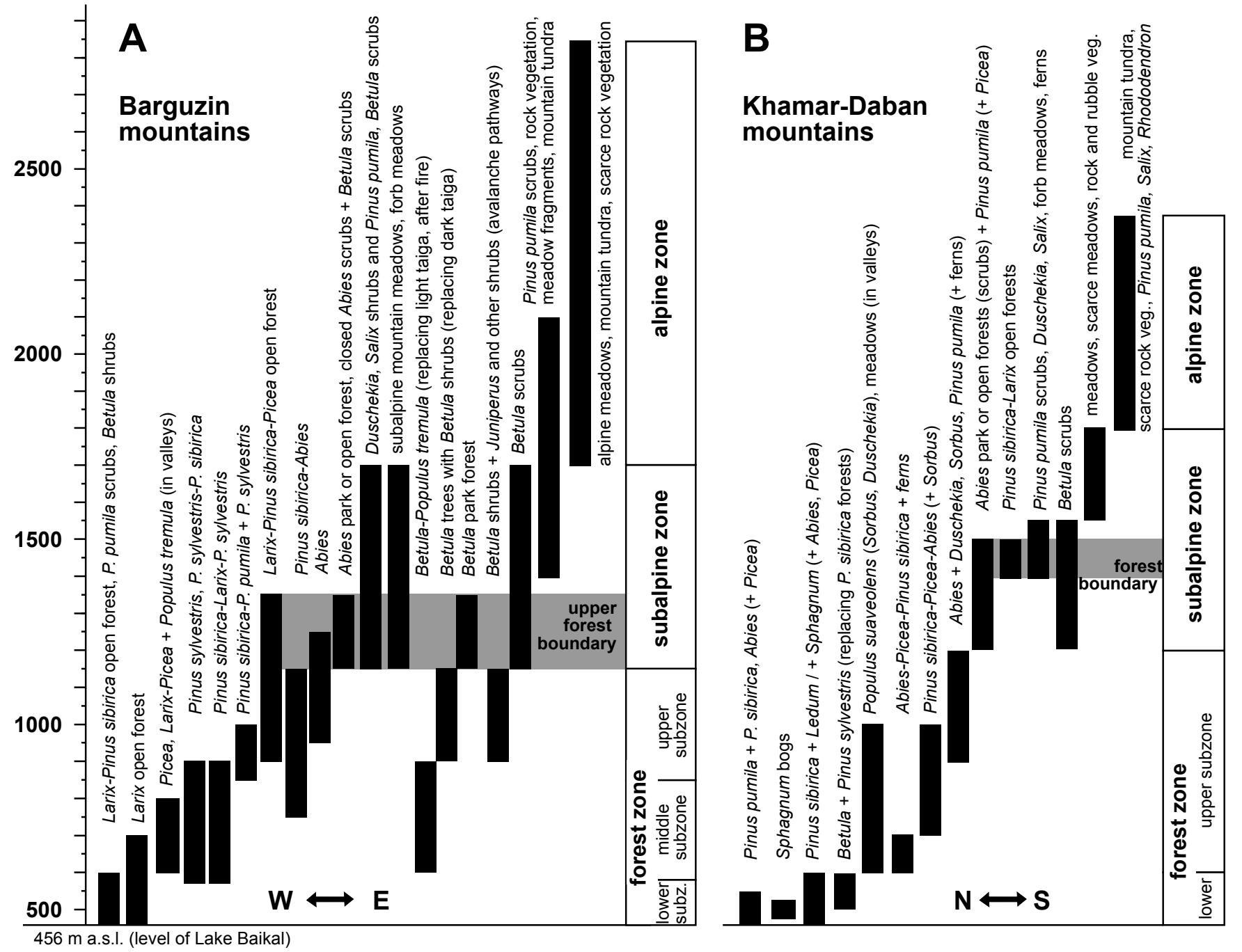

Demske-et-al.,Fig.2 


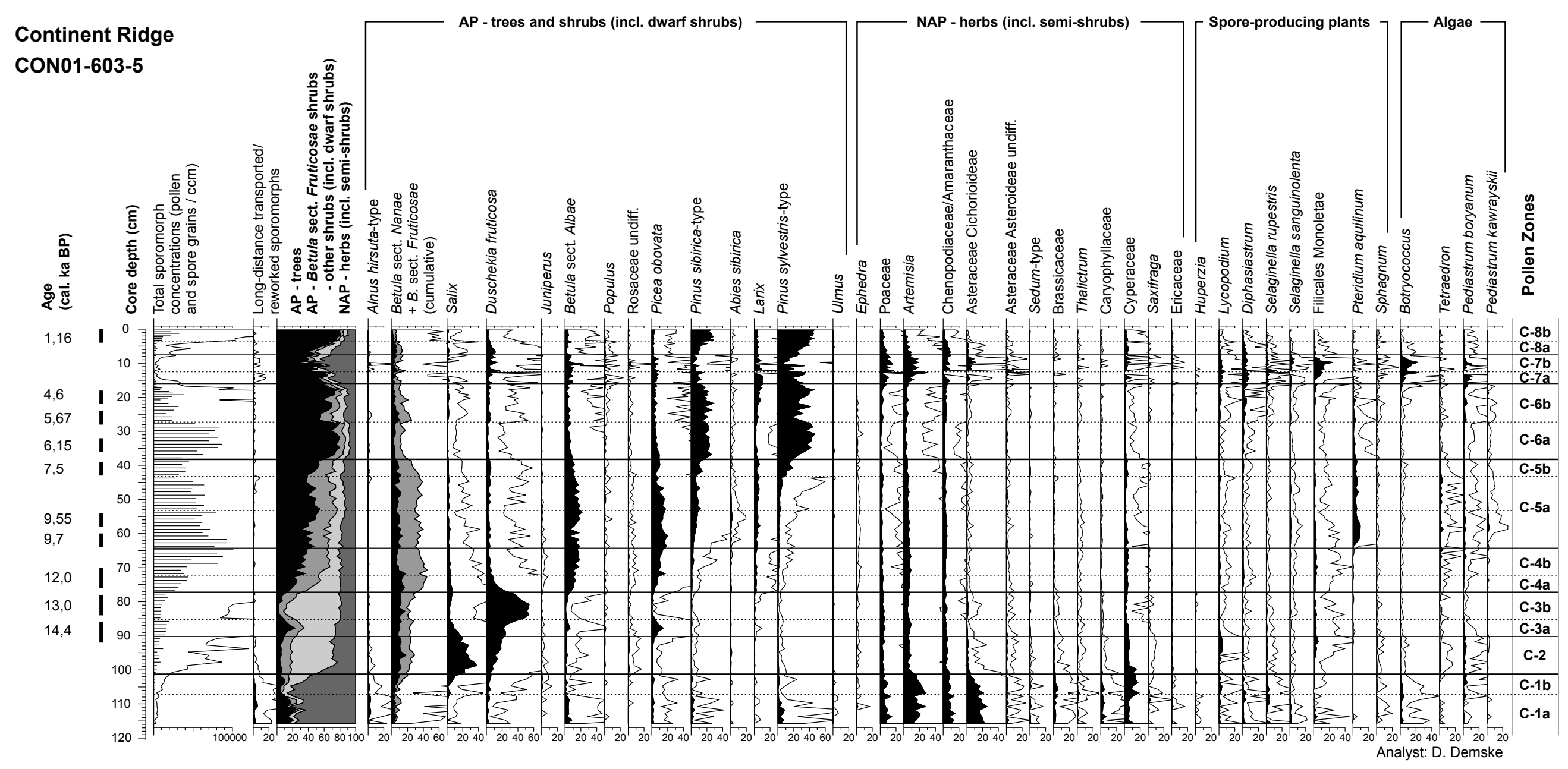

Demske et al., Fig 3 


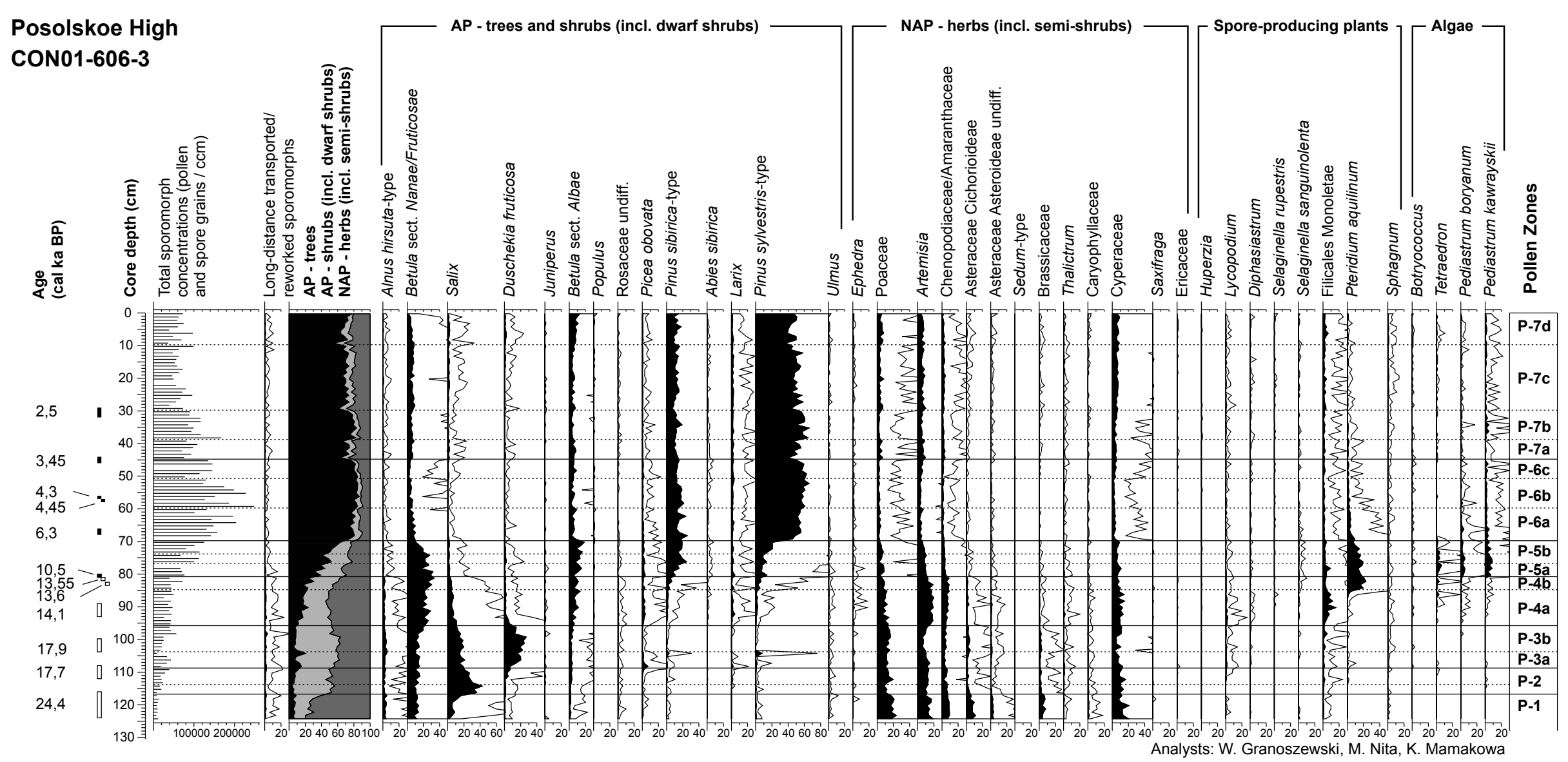

Demske et al., Fig. 4 

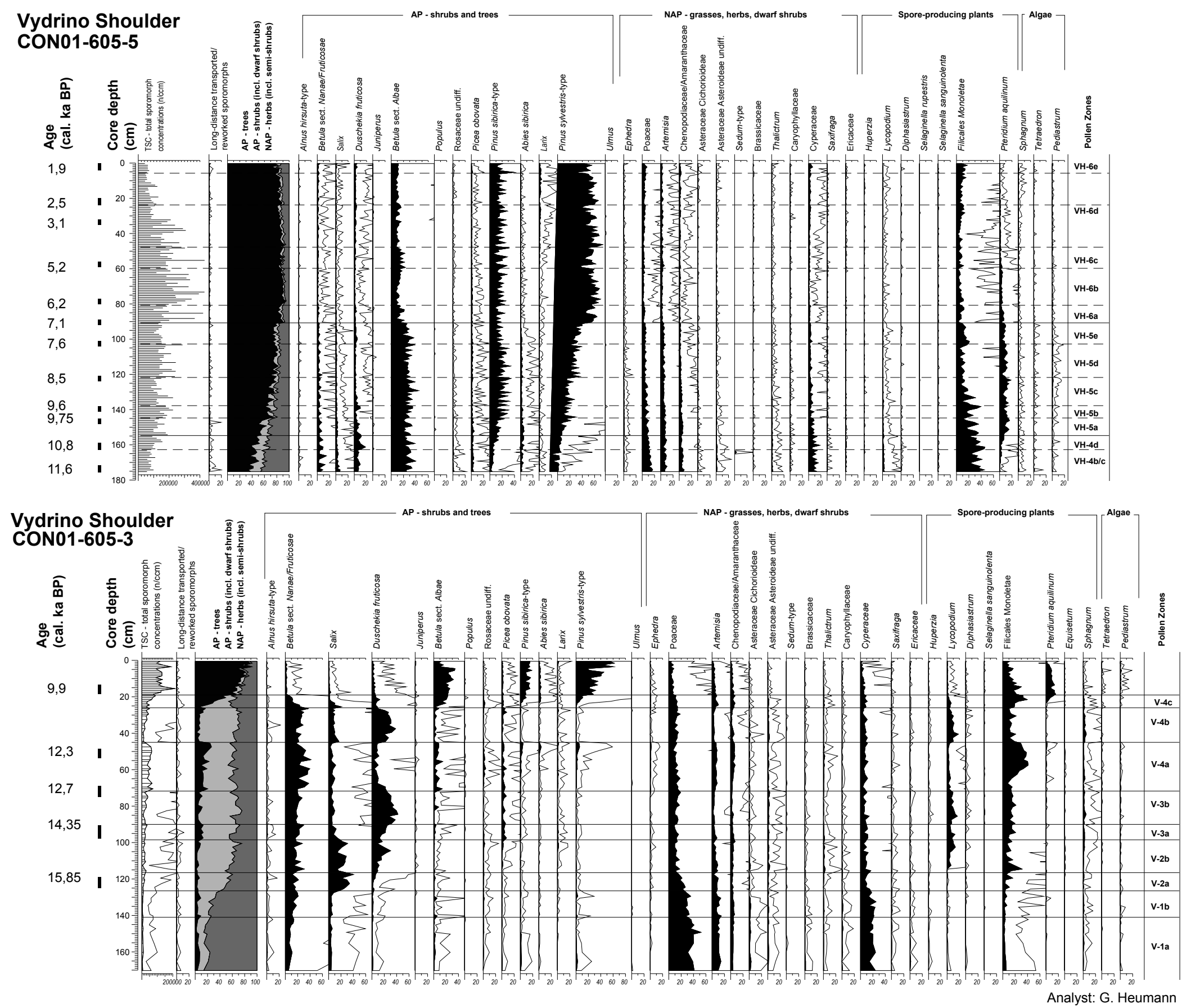

Demske et al., Fig. 5 


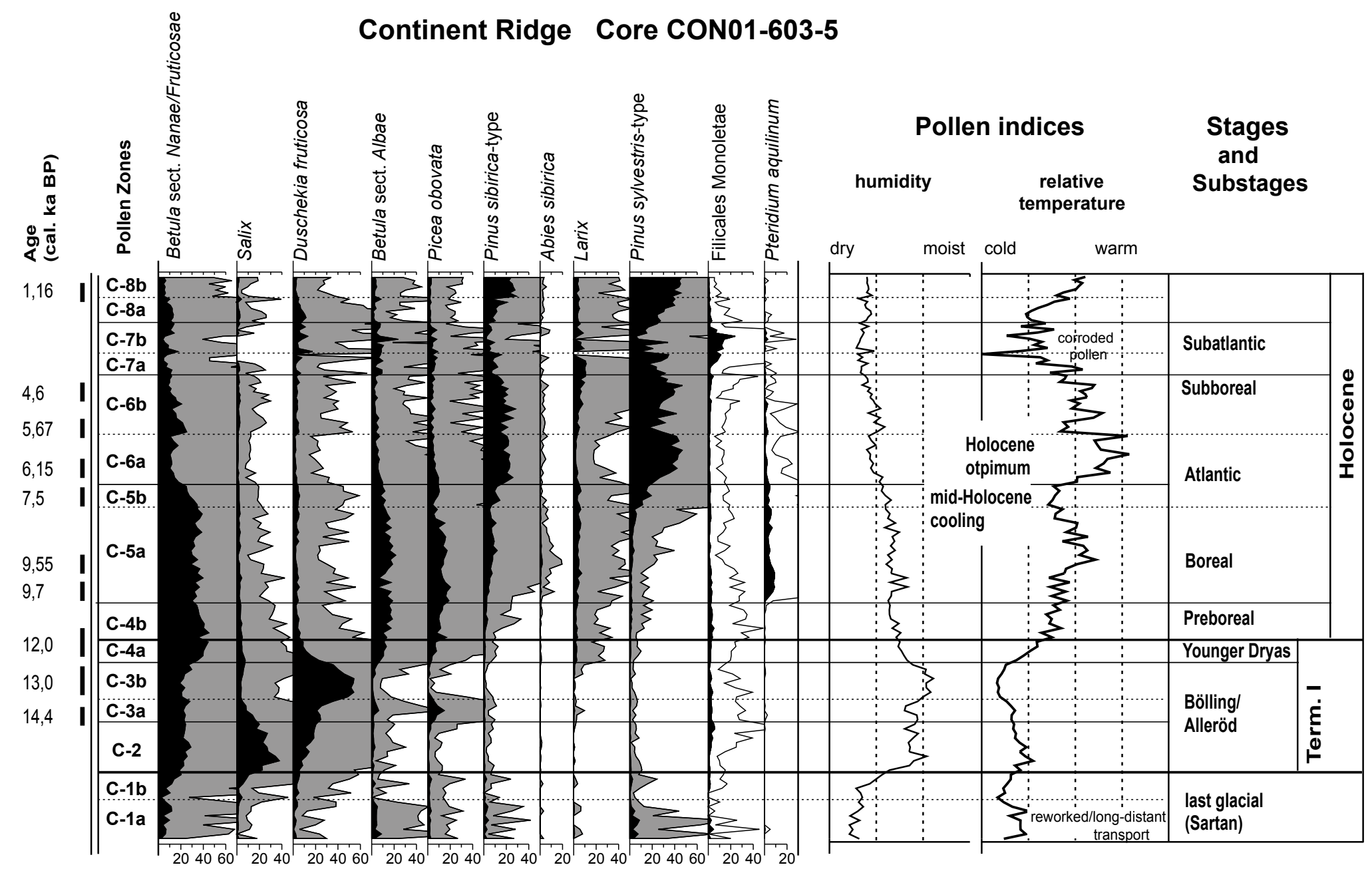

Demske et al., Fig. 6 


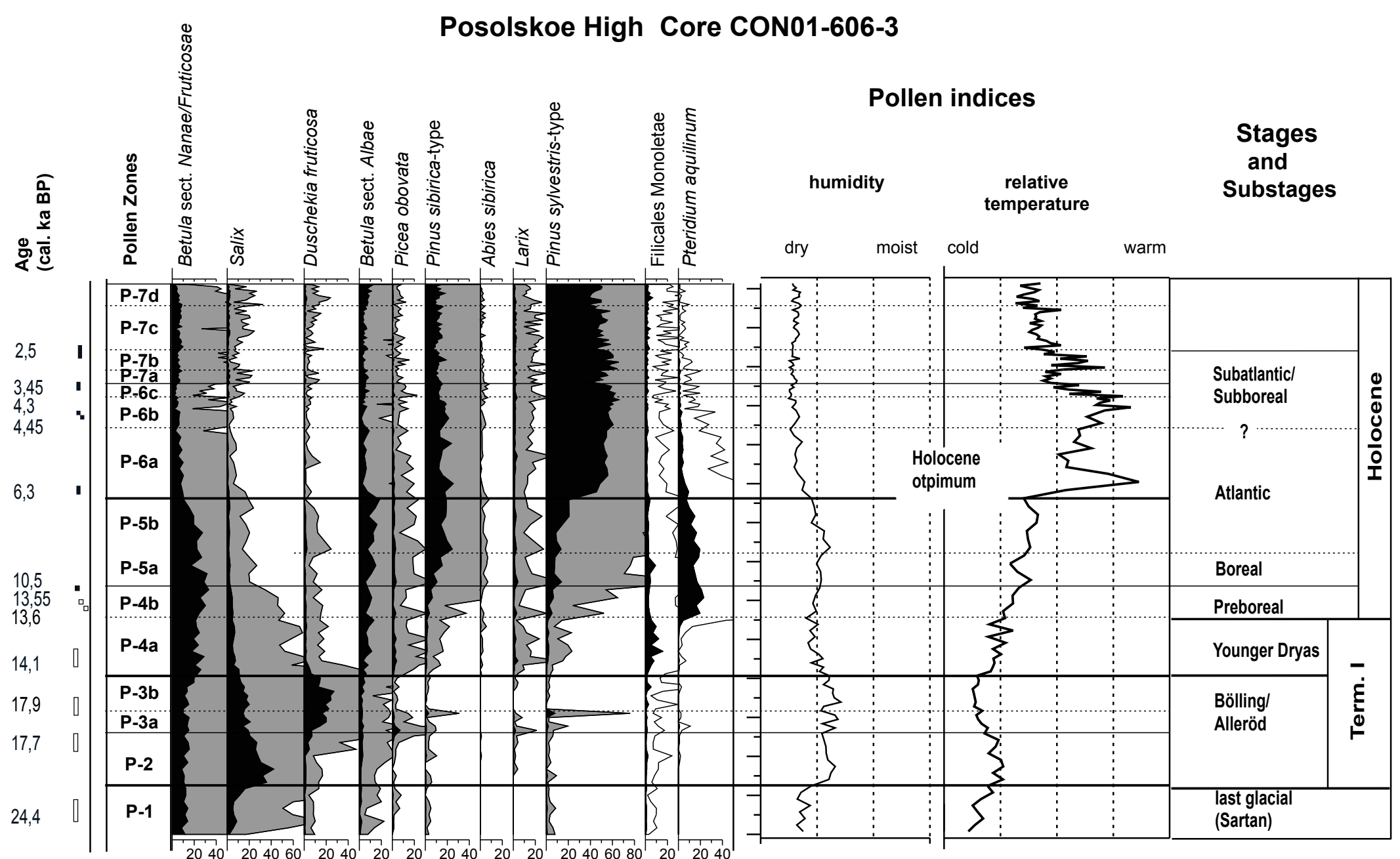

Demske et al. Fig. 7 


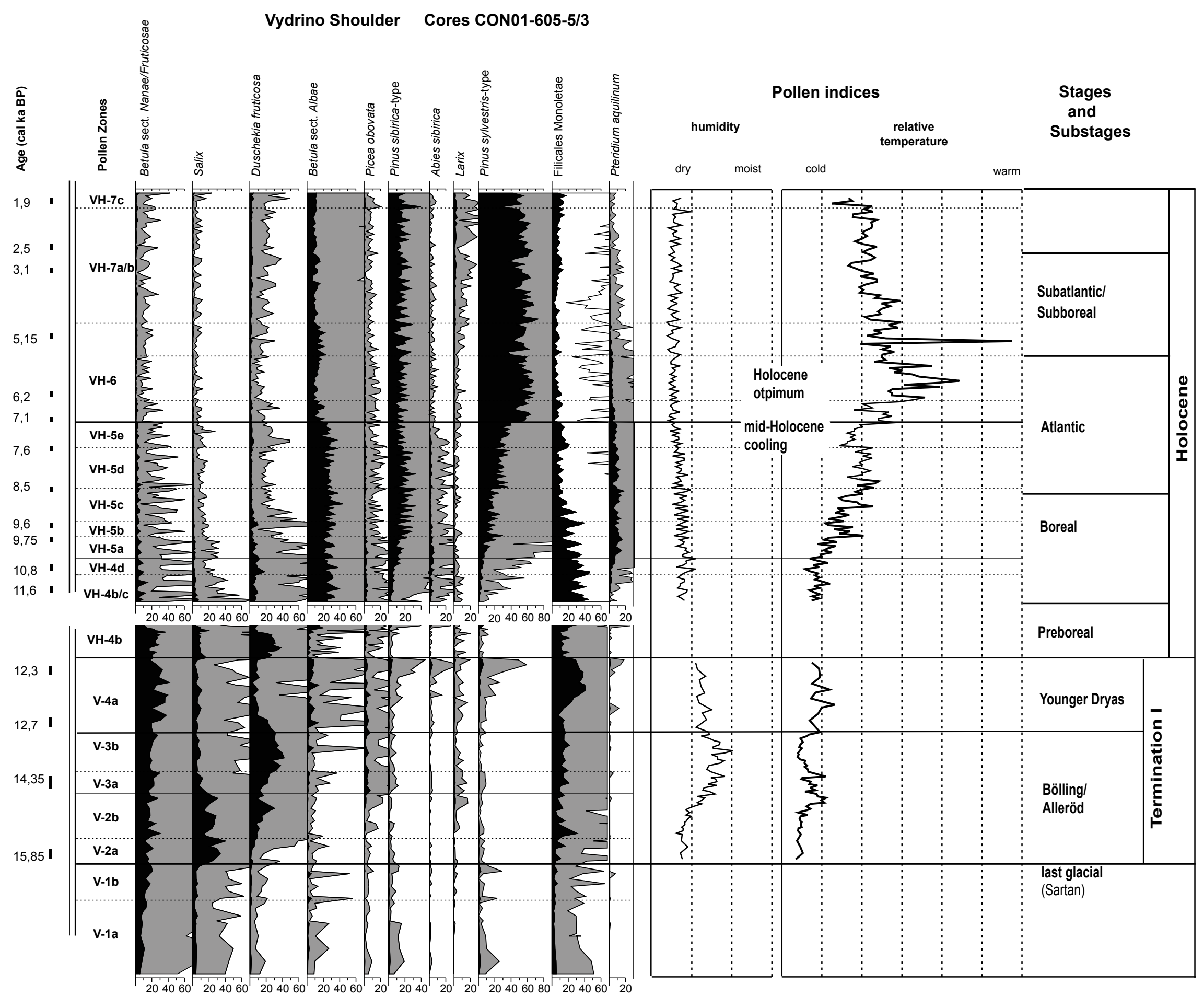

